\title{
1904 St. Louis Dünya Fuarı ve Osmanlı Temsiliyeti: Celal Esad Arseven Sergisi
}

\author{
The 1904 St. Louis World Fair and Ottoman Representation: Celal Esad Arseven's \\ Exhibition
}

\section{Sevil Derin ${ }^{*}$}

\section{Öz}

İlki uluslararası anlamda 1851 yılında Londra'da gerçekleştirilen fuar organizasyonları, Batılı ülkelerin sanayileşme ve kapital ekonomiyi yaygınlaştırma politikaları gereği sonradan dünya çapında düzenli olarak organize edilen etkinliklere dönüşmüştür. Söz konusu fuarlar başta teknoloji, sanat, kültür, zirai ürünler olmak üzere bir ulusu yansıtan bütün öğelerin toplanıp sergilendiği yerlerdir.

XIX. yüzyıl boyunca Osmanlı Devleti'nin bu fuarlara Batı'dan esinlenerek hazırlanılan yeni mimari modelleri içeren çizimler ve çizimlerin reprodüksiyonu, el sanatları ve ziraî ürünlerle katılarak modern dünyadaki yerini kanıtlamaya çalıştığ görülmektedir. Amerika'daki St. Louis kentinin Fransızlardan satın alınmasının 100. yılı dolayısıyla 1904'te düzenlenen fuar da bunlardan biridir. Söz konusu fuarda, fuar komitesi Osmanlı'nın tanıtımı için Kapalı Çarşı ve Türk Mahallesi temasını benimseyerek Celal Esad'dan inşa projesi hazırlamasını istemiştir. Bugün İstanbul Büyük Şehir Belediyesi Atatürk Kitaplığı'nda bulunan bu çizimler, Celal Esad hakkında pek çok araştırma yapılmasına, pek çok yayın bulunmasına rağmen bilinmemektedir. Bu makalede 1903 yılında Celal Esad Arseven tarafından hazırlanan ve 1904 St. Louis Dünya Fuarı'ndaki Türk pavyonunda sergilenen yapıların çizimleri, dünya fuarları ve Osmanlı Devleti'nin bu fuarlarda temsil edilmesi bağlamında incelenmiştir.

\section{Anahtar Kelimeler}

Celal Esad Arseven, St. Louis, Fuar, Mimari, Sergi

\begin{abstract}
The organization of international fairs (the first of which was held in London in 1851), transformed into a regular occurence around the world due to the industrialization and expansion of the capital economy of Western countries. The fairs in question were places where all the elements reflecting a nation - especially technology, art, culture, and agricultural products - were collected and exhibited.

Throughout the 19th century, it was seen that the Ottoman Empire tried to prove its worth in the modern world by participating in these fairs with drawings (including new architectural models inspired by the West and reproductions of these drawings), crafts and agricultural products. One of these was the exhibition held in 1904 for the centenary of the acquisition of the city of St. Louis in America from the French. At the fair in question, the fair committee adopted the theme of the Grand Bazaar and the Turkish Quarter and asked Celal Assad to prepare a construction project on this theme for the promotion of the Ottoman Empire. These drawings, which are in the Atatürk Library of the Istanbul Metropolitan
\end{abstract}

* Sorumlu Yazar: Sevil Derin (Arş. Gör. Dr.), Manisa Celal Bayar Üniversitesi, Fen-Edebiyat Fakültesi, Sanat Tarihi Bölümü, Türk-İslam Sanat Anabilim Dalı, Manisa, İstanbul. E-posta: sevil.derin@cbu.edu.tr ORCID: 0000-0003-4487-9451

Atff: Derin, Sevil. "1904 St. Louis Dünya Fuarı ve Osmanlı Temsiliyeti: Celal Esad Arseven Sergisi." Art-Sanat, 13 (2020): 87-116. https://doi.org/10.26650/artsanat.2020.13.0004 
Municipality, are unknown, even though there has been much research and many publications about Celal Assad. In this article, the structures prepared by Celal Esad Arseven in 1903 and exhibited in the Turkish pavilion at the St. Louis World's Fair in 1904 were examined in the context of world fairs and the representation of the Ottoman Empire in these fairs.

Keywords

Celal Esad Arseven, St. Louis, Fair, Architecture, Exhibition

\section{Extended Summary}

The adventure of the Westernization of the Ottoman Empire extended to the 17th century. Until this century, the empire had no needed for the West (and was even, perhaps, better than the West). After this period the West gained superiority over the Ottoman Empire - not only technically but also as a civilization. In this sense, Westernization was a way to get rid of the underdeveloped living conditions of Eastern societies. First, however, it was necessary to accept the superiority of the West.

Military manufacturing facilities, armouries, shipyards, potassium nitrate factories, steel plants, mines and mints were the main innovations of the Ottoman Empire. At this point, it was seen that the big capitalist states had started to organize world fairs and organize international exhibitions in order to show themselves off, to sell industrial products and to facilitate the search for raw materials, and that the Ottomans participated in these exhibitions by proving that they themselves took part in the civilized world by pushing the limits of its economic conditions.

The idea of the fair was first conceived for the development of the local textile and porcelain industries in London in 1756. After this date, national fairs were held, at regular intervals, until 1847. In 1851, the first international exhibition was organized for economic reasons in England. Many countries in addition to the USA, France, Scandinavian countries, Spain, Portugal, Prussia, Russia, India and the Ottoman Empire participated in this exhibition. The Ottoman Empire participated in the exhibition with agricultural products, tools and handicrafts. Following the exhibition in London, the Ottoman Empire participated in the exhibitions held in Paris in 1855 and again in London in 1862 with similar products but mostly with products belonging to the military industry and mines from various parts of the Empire. The fair held in Paris in 1867 was the first exhibition in which the concept of Ottoman architecture came to the fore and its concrete examples were exhibited internationally. In addition to these products, Ottoman architecture was introduced with various drawings. The drawings consisted of plan, section and facade views of certain buildings in Istanbul and Bursa. After the exhibition in France, exhibitions were arranged in Vienna in 1873, Paris in 1889, Chicago in 1893 and again in Paris in 1900 and Ottoman architecture was represented with reproductions and drawings in all of them. Their common features were that they were all prepared by foreign architects. 
The St. Louis World Fair (which was originally planned to be held in 1903 but had to be postponed for one year for wider participation), was the third largest fair in the United States. The city of St. Louis was influenced by the successful results of an international exhibition held in 1893 in Chicago. As its rival, and to celebrate the 100th anniversary of the acquisition of the city from the French in 1803, a fair with similar participation was planned to be held there.

In the same year, Celal Esad Arseven met an American named Pangalo in Beyoğlu. Pangalo advised him to prepare a project on the neighborhoods and bazaars of old Istanbul and to participate in the competition at the exhibition to be opened in St. Louis, USA. The project of Celal Assad - prepared in less than a month - was accepted and he received an invitation from America to attend the fair. However, he could not go to the United States at that time due to some restrictions on his travels abroad.

Although he could not attend, people later learned of the event from the published fair bulletin which included a reproduction of Celal Assad's drawings. In this article, the Grand Bazaar was likened to a maze connected by columns and vaults. It was speculated as having 300 shops with 240 of them belonging to different businesses. The bazaar was described as having an Oriental or Turkish architectural style. Then, it was stated that the selection of the section of the Grand Bazaar to be exhibited was a difficult decision for the selection committee and the door on the side of a mosque known as Nur-u Osmaniye was chosen and 11 drawings of the street views of Kalpakç1lar Street and the bazaar extending straight from east to west were mentioned. According to the article, Celal Bey said in a statement about the fair that he accepted this work because he wanted to prevent the misrepresentation and disreputation of the Turkish image and to increase the prestige of the Sultan. The article ended by stating that Pangalo was the owner of the Egypt-St. Louis exhibition company and he signed an agreement with the Eames \& Young Company to exhibit and reproduce Mr. Celal's drawings.

Today, in the Atatürk Library of the Istanbul Metropolitan Municipality, Celal Esad Arseven's 14 drawings including 11 street drawings of the Grand Bazaar and street and facade drawings of Turkish houses can be accessed. It was understood from the Roman numerals on the drawings that there were 15 drawings. On the basis of the drawings, a small imitation of the Grand Bazaar was made and this reproduction was created in the name of the Turk or the Istanbul pavilion, and these drawings were exhibited in this pavilion. When the drawings signed by Celal Assad and the drawings that he had stated as having been prepared for the St. Louis fair were examined, it was understood that the exhibited part was different from the reality. The drawing number XIII, possibly containing a house or street view, could not be accessed. The first drawing numbered I was the plan of the bazaar, which included the section between 
Nur-u Osmaniye and Beyazıd and showed the Kalkapçılar Bazaar to a great extent. The next 10 drawings displayed the Grand Bazaar, illustrated from various angles. The remaining 4 drawings included street and facade drawings of Istanbul neighborhoods and Turkish houses.

This presentation, mediated by the American Pangalo, undoubtedly opened new horizons for Celal Esad Arseven and formed the basis of his knowledge and research on Turkish architectural history. After preparing this project, he published his research as a book prepared in French, and this book was praised even at the time of writing. Celal Esad Arseven is still an important figure in Turkish art history and his works and masterpieces deserve to be highlighted. 


\section{Giriș}

Osmanlı İmparatorluğu'nda Batılılaşma hareketinin başlangıc1 XVII. yüzyıla kadar uzanmaktadır. ${ }^{1}$ Bu yüzyıla kadar imparatorluk Batı'dan çok daha iyi durumdadır. $\mathrm{Bu}$ yüzyıldan itibarense Batı artık Osmanlı için yalnızca teknik değil aynı zamanda medeni bir üstünlük de sergilemeye başlamıştır. Bu anlamda Batılılaşmak Doğu toplumlarının içinde bulunduğu geri kalmış hayat şartlarından da kurtulmaktır. Bunun için her şeyden önce Batı'nın üstünlüğünü kabul ve itiraf etmek gerekmektedir. ${ }^{2}$

Viyana bozgunundan sonra Yirmisekiz Mehmed Çelebi'nin Avrupa izlenimleri ve hayranlığı XVIII. yüzyılda taklit edilen bir prestij-kültür hâlinde imparatorluğa yans1mıştır. Bunun ilk göstergesi de zengin kişilerin evlerinde Rokoko mimarisinde, frenk eşyası ile döşeli frenk odalarının oluşturulmaya başlanmasıdır. ${ }^{3}$ Yönetim, imparatorluğu Avrupa seviyesinde ilerlemeye dâhil edebilmek için XVIII. yüzyılın sonunda bir dizi modernleşme politikası uygulamış ve XIX. yüzyılda Tanzimat'ın ilanıyla sürdürülen teknoloji, yönetim, hukuk ve eğitim alanlarında Avrupa'yı örnek alan reformlar 1923 'te Cumhuriyet'in kurulmasıyla en üst seviyeye çıkmıştır. ${ }^{4}$

\section{Osmanlı Ekonomisi, Kültürü ve Mimari Prestiji Bağlamında Dünya Sergileri}

Askeri imalat tesisleri, tophane, tersane, güherçile fabrikaları, çelikhane, madenler ve darphane Osmanlı'nın Batı'dan aldığı yeniliklerin başında gelmektedir. ${ }^{5}$ Bu noktada büyük kapitalist devletlerin kendini göstermek, sanayi ürünlerini satabilmek ve hammadde arayışını kolaylaştırabilmek için dünya çapında fuarlar organize etmeye ve uluslararası sergiler düzenlemeye başladığı, Osmanlı'nın bu sergilere kendilerinin de uygar dünya içinde yer aldığını kanıtlamak için her seferinde maddi şartlarını zorlayarak katıldığı görülmektedir. Söz konusu fuarlara katılımlar çoğunlukla Sultan Abdülaziz (1861-1876) ve Sultan II. Abdülhamid'in (1876-1909) isteğiyle olmuştur. Sultan Abdülaziz Batılılaşma çabalarını hevesle desteklerken Sultan Abdülhamid bir yandan İslam idealleri peşinde koşan, bir yandan Batı reformlarına sarılan bir görünüm çizmiştir. ${ }^{6}$ Özellikle XVIII. yüzyılda doğu ülkelerine büyük bir ilgi vardır ve Doğu ile ilgili olmak prestijli bir durum yaratmaktadır. XIX. yüzyılda ise Batı'nın

1 Halil İnalcık, Osmanlıların XIX. yüzyıla kadar yalnız teknik gelişmeleri almayı kabul ettiğini, bu yüzyıldan itibaren idare, kanun ve gelenekler anlamında bir taklit olduğunu belirtmekte ve bu asırdan önce sıkı kültür teması sonucu bazı âdetlerin alındığı görülse de bunun toplum nezdinde pek hoş karşılanmadığını dile getirmektedir. Bkz. Halil İnalcık, “Osmanlılar'da Batı'dan Kültür Aktarması Üzerine,” Osmanlı İmparatorluğu-Toplum ve Ekonomi (İstanbul: Eren Yayınları, 1993), 14-15.

2 Tarık Zafer Tunaya, Türkiye'nin Siyasi Hayatında Batılılaşma Hareketleri (İstanbul: Yedigün Matbaası, 1960), 18.

3 İnalcık, "Osmanlılar'da Batı'dan Kültür Aktarması Üzerine," 426-27.

4 Zeynep Çelik, Displaying the Orient-Architecture of İslam at Nineteenth-Century World's Fair (Berkeley: University of California Press, 1992), 6.

5 İnalc1k, “Osmanlılar'da Batı'dan Kültür Aktarması Üzerine,” 428.

6 Çelik, Displaying the Orient-Architecture of Islam at Nineteenth-Century World's Fair, 6. 
Doğu'dan daha üstün olduğu siyasi söylemleri sebebiyle Osmanlı egzotik doğu imajını reddetmek istemiştir. Ancak çelişkili bir şekilde, ilgi toplayabilmek için Batı'nın beğendiği oryantalist öğeleri kullanmaktan da kaçınmamıştır. Uygar devletlerin temsil edildiği dünya fuarlarında Osmanlı hem İslam dünyasının lideri olan bir İslam ülkesi hem de uygar dünyanın bir üyesi olarak yer almıştır. ${ }^{7}$

Fuar fikriyse, Osmanlı’ya benzer şekilde, Batılı devletlerin kendilerinin gelişmişlik seviyesini sergileme arzuları neticesinde ortaya çıkmıştır. İlk olarak yerel düzeyde Londra'da, 1756'da tekstil ve porselen sanayisini geliştirmek için fuar düzenlenmiştir. Bu tarihten sonra belirli aralıklarla 1847'ye kadar ulusal fuarlar yapılmıștır. ${ }^{8} 1851$ 'de İngiltere merkezli bir ekonomik düzen kurmak amacıyla ilk uluslararası sergi hazırlanmıştır. Bu fuarda endüstriyel makineler, ürünler ve sanat eserleri sergilenmiş, yalnız sanayi ve ekonomide değil barış, ilerleme, refah ve üretim ahlakının dünyanın geri kalanına gösterilmesi amaçlanmıştır. İngilizler fuarları aynı zamanda kimliğin inşasında da önemli bir araç olarak kullanmıştır. Teşhir edilmek üzere sömürge ülkelerindeki insanları bu fuarlara getirmişler, İngiliz kimliği karşısında bu yoksul ve zavallı insanların sömürülmeyi hak ettiği fikrini benimsetmişlerdir. 1851 'deki bu fuarda sonraki yüz yıl boyunca görülecek olan insan hayvanat bahçesi bölümü büyük ilgi toplamıştır. ${ }^{9}$ İnsanlık sınıflandırmasında bütün dünya ulusları gelişmişlik durumuna göre yerini almıştır. ${ }^{10}$ (G. 1) Uluslararası düzeydeki bu ilk sergiye ABD, Fransa, İskandinav ülkeleri, İspanya, Portekiz, Prusya, Rusya, Hindistan ve Osmanlı Devleti yanında pek çok ülke katılmıştır. Osmanlı Devleti sergiye zirai ürünler, araç gereç ve el işleriyle katılmıştır. ${ }^{11}$

7 Nurcan Yazıcı, “19. Yüzyı1 Uluslararası Sergilerinde Bir Osmanlı Simgesi-III. Ahmet Çeşmesi," Toplumsal Tarih 134 (2005), 84.

8 İbrahim Şirin, “Dünya Fuarları ve Osmanlı Modernleşmesi," History Studies 9/2 (2017): 190.

9 Şirin, "Dünya Fuarları ve Osmanlı Modernleşmesi," 191.

101904 St. Louis Fuarıyla ilgili bir kitapta ulusların gelişmişlik sırasını gösteren bir resim yayımlanmıştır. Resimde Türklerin gelişim aşaması, Avrupalı Amerikanlar, Ruslar, Japonlar ve Hintlilerden sonra 5. sırada gösterilmiștir. Bkz. Louisiana and the Fair: An Exposition of the World, Its People, and Their Achievements 5, ed. James William Buel, (St. Louis: World’s Progress Publishing Company, 1904), erişim 1 Şubat 2019. https://babel.hathitrust.org/cgi/pt?id=uc2.ark:/13960/t1 cj89b26;view=1up;seq=10.

111851 Londra Fuarı hakkında ayrıntılı bilgi ve sergilenen ürünlerin tamamı için bkz. Rıfat Önsoy, "Osmanlı İmparatorluğu'nun Katıldığı İlk Uluslararası Sergiler ve Sergi-i Umumi-i Osmani 1863 İstanbul Sergisi,' Belleten 185 (1983): 198-199. 


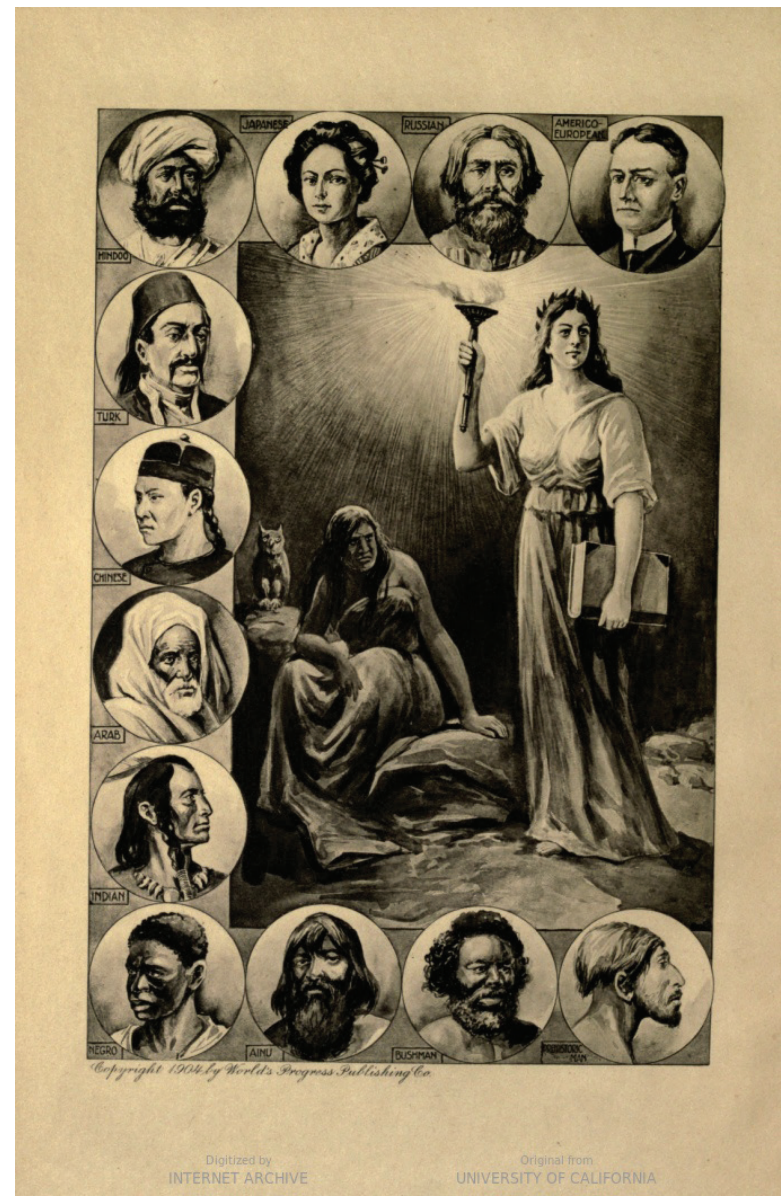

G. 1. Fuar tanıtım kitabında "insanlığın gelişim aşaması"

(Louisiana and the Fair: An Exposition of the World, Its People, and Their Achievements, 1904)

Londra'daki serginin ardından 1855 'te Paris ve 1862 'de yeniden Londra'da düzenlenen sergilere Osmanlı devleti benzer ürünlerle ancak daha çok askeri sanayiye ait ürünler ve imparatorluğun çeşitli yerlerinden çıkarılan madenlerle katılmıştır. ${ }^{12}$

XIX. yüzyılın ilk yarısından başlayarak iç karışıklıklar ve savaşlar sebebiyle imparatorluk dağılma tehlikesi yaşamaktadır. Dağılmayı geciktirmek ya da engellemek için yapılan ıslahatlarsa sonuç vermemiştir. 1856 Paris Antlaşması ile bir barış ortamına girilmiş, ekonomiyi içinde bulunduğu durumdan çıkarmak için yeni önlemler alınmaya çalışılmıştır. Batı'nın üretim tekniğini alarak onunla rekabet etmeyi öngören bir dizi tedbir arasında ülkede üretilen malların kalite, fiyat ve çeşitlerini görmek, üreticinin sorunlarını çözmek ve başarılı olanların ödüllendirilmesi için İstanbul'da bir sergi düzen-

12 Önsoy, "Osmanlı İmparatorluğu’nun Katıldığı İlk Uluslararası Sergiler ve Sergi-i Umumi-i Osmani 1863 İstanbul Sergisi," 205-206. 
lemek de vardır. ${ }^{13} \mathrm{Bu}$ serginin diğerlerinden farkı Osmanlı'nın sanayileşme ve ekonomi alanlarındaki eksik ve hatalarını görerek çözüm arayışına girmek istemesidir. ${ }^{14}$ Sergi-i Umumi-i Osmani olarak adlandırılan ve 1863 'te gerçekleştirilen sergi için Sultanahmet Meydanı'nda Dikilitaş'ın kuzeyinde 3500 metre karelik bir fuar alanı inşa edilmiştir. Binanın mimarı Bourgeois'tir ve iç dekorasyonu Léon Parvillé tarafından yapılmıştır. ${ }^{15}$

İlk kez mimari düzenleme ve tanıtıma yer verilmesi bakımından Osmanlı'nın katıldığ en önemli sergi olarak gösterilen 1867 Paris sergisi, Sultan Abdülaziz'in ziyareti sebebiyle de ayrı bir önem taşımaktadır. Ana teması "çalışma tarihi" olan sergiye Fransa'dan sonra en fazla katılımcı Osmanlı İmparatorluğu'ndan olmuştur. ${ }^{16}$ Osmanlı kendisine ayrılan bölümde Léon Parvillé, Barborini işbirliği ve Montani’nin katkılarıyla cami, köşk ve hamamdan oluşan, orta alanda havuz-fiskiye düzenlemesinin olduğu üçlü bir yapı grubu hazırlanmıştır. 1867 Paris sergisi, Osmanlı mimarisi kavramının ilk kez gündeme geldiği, somut örneklerin uluslararası alanda sergilendiği ilk sergidir. Bu ürünler yanında Osmanlı mimarisi çeşitli çizimlerle de tanıtılmıştır. Çizimler, İstanbul ve Bursa'daki bazı yapıların plan, kesit ve cephe görünümlerinden oluşmaktadır. ${ }^{17}$

Fransa sergisinden sonra 1873'te Viyana, 1889'da Paris, 1893'te Şikago ve 1900 y1lında yeniden Paris sergileri yapılmış ve hepsinde Osmanlı mimarisi reprodüksiyon ve çizimlerle temsil edilmiştir. Bunların ortak özellikleriyse hepsinin yabancı mimarlar tarafından hazırlanmış olmasıdır. 1867'de Paris'te yapılan mimari sunumların aksine daha çok XVIII. yüzyıl Osmanlı mimari örneklerini içermekte ve Batı'nın Oryantalizm beklentilerini karşılamaktadır. 1873 Viyana sergisinde o dönem Avrupa'da ilgi çeken ve Osmanlı mimarisinin her dönemine ait bir motif bulunduran 1728 tarihli III. Ahmet Çeşmesi seçilmiştir. 1889 Paris sergisine III. Ahmet Çeşmesi’nin bir yorumu olan ve tütün pavyonu olarak adlandırılan bir binayla katılım sağlanmıştır. Şikago sergisine de Osmanlı'nın geniş katılımı söz konusudur ve yine III. Ahmet Çeşmesi'nin Türk çarşısı yorumuyla karşımıza çıkmaktadır. Ayrıca 1893 Şikago sergisindeki Türk köyü sunumunda hem işlevsel hem sergi amaçlı bir cami ve Mısır Çarşısı'nın bir örneğine yer verilmiştir. ${ }^{18}$

131894 'te benzer heveslerle İstanbul'da yapılması planlanan başka bir sergi ise aynı yıl gerçekleşen depremden kaynaklanan ekonomik koşullar nedeniyle iptal edilmiştir. Çelik, Displaying the Orient-Architecture of İslam at Nineteenth-Century World's Fair, 6; Hatice Adıgüzel, "Bir Tasarımın İzinde: Yeni Bulgular Işığında Raimondo D'Aronco'nun İlk İstanbul Projesi Dersaadet Ziraat ve Sanayi Sergi-i Umumisi," METU JFA 36, no. 1 (2019): 157-182, erişim 19 Kasım 2019, http://jfa.arch.metu.edu.tr/archive/0258-5316/articles/ metujfa2019104.pdf.

14 Önsoy, “Osmanlı İmparatorluğu’nun Katıldığı İlk Uluslararası Sergiler ve Sergi-i Umumi-i Osmani 1863 İstanbul Sergisi," 207.

15 Sergi binası ve sergiyle ilgili ayrıntılı bilgi için bkz. Nurcan Yazıcı, "Uluslararası Sergilerde Osmanlı Mimarisi'nin Sunumu," Arkitekt 500 (2004): 23.

16 Yazıcı, "Uluslararası Sergilerde Osmanlı Mimarisi'nin Sunumu," 23.

17 Binaların mimari detayları ve çizimler bilgi için bkz. Yazıcı, "Uluslararası Sergilerde Osmanlı Mimarisi'nin Sunumu," 24-25.

18 Yazıc1, "Uluslararası Sergilerde Osmanlı Mimarisi’nin Sunumu,” 25-29. 
1900 Paris sergisineyse Osmanlı Devleti oldukça fazla para harcamıştır. Sergi için tek bir bina inşa ettirilmiştir. Yapı, geniş bir sivri kemer düzenlemeli, revaklı ve iki katlı olarak kurgulanmıştır. Bina, Türk-İslam mimarisiyle Kuzey Afrika Mimarisi karışımı eklektik bir sunum içermektedir. Bu serginin en önemli tarafıysa Osmanlı pavyonunun İtalya ve Amerika pavyonları arasında Batılı ülkelerin parçası gibi yer almış olmasıdır. ${ }^{19}$

\section{Celal Esad Arseven (1875-1971) Kimdir?}

Çalışmanın konusunu oluşturan 1903 tarihli St. Louis Dünya Fuarı'nda Osmanlı pavyonunun mimarı olan Celal Esat Arseven, sanat tarihi disiplininin de başlıca kurucuları arasında yer almış, Osmanlı'nın son dönem aydın kuşağı ve cumhuriyetin Osmanlı'dan devraldığı bürokrat kadrosu içinde yetişmiş önemli bir isimdir. Osmanlı devletinin çağdaşlaşma politikaları gütmeye devam ettiği son döneminde, kendini Batılı anlamda yetiştiren kişilerden oluşan bir düşünce ortamında sanatsal ve ilmî faaliyetlerde bulunmuş değerli bir fikir insanıdır. Bir asra yaklaşan yaşamı boyunca başta resim olmak üzere sanat tarihi, müzik, tiyatro ve sinema dallarında eserler vermiş, çeşitli dergi ve gazeteler çıkarmış, kitaplar yazmış ve bürokratik görevlerde bulunmuş çok yönlü bir kişidir. ${ }^{20}$ (G. 2)

19 Yazıcı, "Uluslararası Sergilerde Osmanlı Mimarisi'nin Sunumu,” 29, 31.

20 Bu bölümde sanatçının yaşamının genel hatları ve eserlerine kısaca değinmekle yetinilecektir çünkü Celal Esad Arseven hakkında şimdiye kadar çok sayıda biyografi niteliğinde eser yayımlanmıştır. Bunun haricinde eserleri üzerine de çok sayıda inceleme yapılmış, Arap harfli ya da Fransızca olarak yazdığı bazı eserler günümüz Türkçesi’ne çevrilmiştir. Bunlardan daha çok biyografi niteliğinde olanlarının büyük kısmına Semavi Eyice ve Feridun Akozan yazılarında yer vermiştir. Celal Esad Arseven yaşamı ve eserleri hakkında geniş bilgi için bkz. Feridun Akozan, “Celal Esad Arseven'in Biyografisi," Demirbaş No: Bel_Mtf_003701, erişim 7 Mart 2019 http://ataturkkitapligi.ibb.gov.tr/kutuphane3/Evraklar/Bel_Mtf_003701.pdf; Semavi Eyice, "Celal Esad Arseven, 1875-1971,” Belleten 36 (1972): 173-202. Diğer başlıca eserler için ayrıca bkz. Celal Esad Arseven Anısına Sanat Tarihi Semineri Bildirileri, ed. Banu Mahir (İstanbul: Mimar Sinan Üniversitesi Matbaas1, 2000). Celal Esad Arseven, Sanat ve Siyaset Hatıralarım, ed. Ekrem Işın (İstanbul: İletişim Yayınları, 1993); Celal Esad Arseven, Eski Galata ve Binaları, ed. Dilek Yelkenci (İstanbul: Çelik Gülersoy Vakfı Yayınları, 1989); Celal Esad Arseven, Güzel Sanatlar Terimleri Alanında Öncü Bir Çalışma, Sanâyi'-i Nefìse Istılâhâtı Mecmûası, haz. Nurcan Yazıcı (İstanbul: Mimar Sinan Güzel Sanatlar Üniversitesi Yayınları, 2000); Celal Esad Arseven, Osmanlı Dönemi Mimarlık Sözlüğ̈̈, Istılâhât-ı Mi'mariyye, çev. Şeyda Alpay (İstanbul: Kaknüs Yayınları, 2017). 


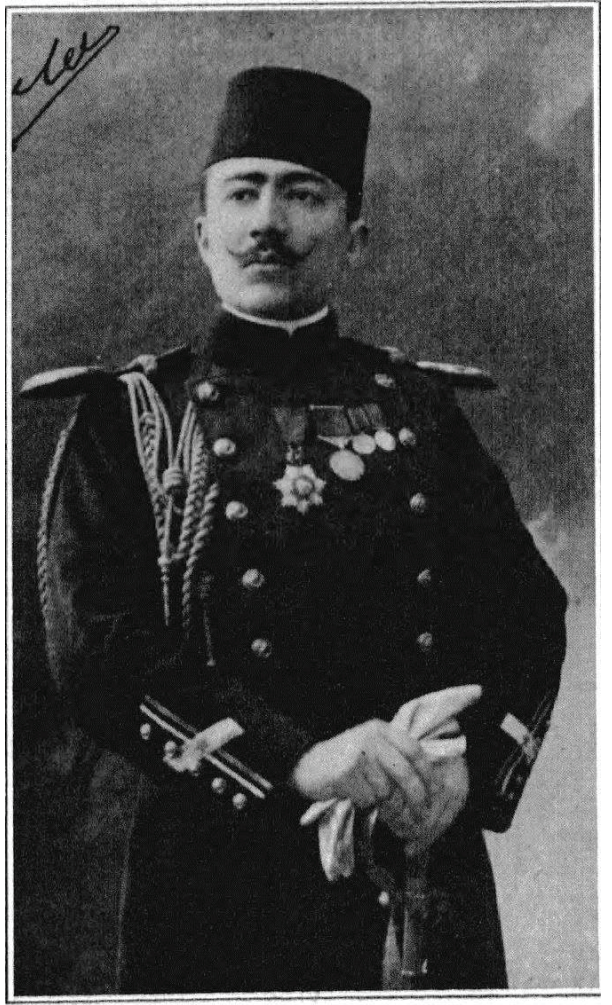

DJELAL BEY BEN ESSAD

G. 2. Celal Esad Bey (World Fair's Bulletin, July 1903)

Asıl adı Mehmed Celaleddin olan Celal Esad Arseven 1875'te Beşiktaş'ta doğmuştur. Annesi Sakızlı Mustafa Efendi’nin kızı Fatma Suzidil Hanım, babası Tanzimat döneminin önemli figürlerinden Sadrazam Ahmed Esad Paşa'dır. Babasının erken ölümü nedeniyle amcası Kazım Paşa'nın yanında yetişmiştir. ${ }^{21}$ İlköğrenimini evinin yakınındaki Taşmektep’te ve Hamidiye Okulu'nda yapmış, 1885'te Beşiktaş Askeri Rüştiyesi'nde, 1888'de de Galatasaray Mekteb-i Sultanisi'nde öğrenimine başlamıştır. Kısa süre sonra buradan ayrılıp 1889'da Mekteb-i Mülkiye'ye geçmiştir. Bu zaman zarfında Sanayi-i Nefise Mektebi'ne de bir süre devam etmiştir. Babası asker olduğu için Sultan II. Abdülhamid'in (1842-1918) iradesi ile Mekteb-i Harbiye'de öğrenim görmesi istenmiş, 1891 senesinde askeri okulun Zadegân sınıfına kaydolmuş, buradan mülazım (teğmen) olarak mezun olmuştur. ${ }^{22}$ Harbiye'deki öğrenimi sırasında Türk resminin önde gelen isimlerinden Hoca Ali Rıza'dan dersler alma firsatı bulmuştur. Yine askerliği sırasında Türk-Yunan savaşı başladığında Yıldız Sarayı'nda Sultan II. Abdülhamid'in yaverliği görevine atanmıştır. ${ }^{23}$

21 Arseven, Eski Galata ve Binalart, 9.

22 Eyice, "Celal Esad Arseven, 1875-1971," 175-176.

23 Arseven, Sanat ve Siyaset Hatıralarım, 15. 
Mekteb-i Harbiye'den sonraki yıllarda Celal Esad tamamen sanata yönelmiştir. Cihangir'de bir evde yaşayan ve yaptığı resimlerle geçimi sağlayan Ressam Zonaro ile tesadüfen tanışmış ve kendisinden resim dersleri almıştır. ${ }^{24}$ Viyana, Paris ve Berlin'e gidişi bu dönemden sonradır. Avrupa'nın çeşitli yerlerinde, çeşitli tekniklerde resim dersleri almış, 1895-1903 yılları arasında resim tekniğine ilişkin Resim Kütüphanesi başlıklı bir dizi kitap yayınlamıştır. Celal Esad'ın şehir tarihi ve mimari tarihe yönelmesiyse 1903 yılı itibariyledir. Aynı yıl St. Louis fuarı için hazırladığı eskizler ve yaptığı araştırmalar, kendi anlatımıyla, daha sonradan 1910 yılında Paris'te basılacak olan Bizans ve Osmanlı Döneminde İstanbul konulu kitabın da alt yapısını oluşturmuştur. $^{25}$

Celal Esad'ın söz konusu sergi için yaptığı araştırma ve projelerin mimarlık tarihine ilişkin ilk ciddi çalışmaları olduğu anlaşılmaktadır. Sonrasında II. Meşrutiyet'i (1908) takip eden yıllarda resmi görevi olmaksızın yazılar yazmış, sanat ve arkeoloji araştırmaları yapmak için yurtiçi ve yurtdışında yaşamıştır. 1912'de Galata Tahrir-i Müsakkafat Reisliğine (bina kayıt dairesi) atanarak uzun aradan sonra ilk resmî görevini almıştır. Bir sene sonra Şehremaneti Umur-1 Fenniye ve İstatistik müdürü, I. Dünya Savaşı yıllarında da Kadıköy Belediye Dairesi Başkanı olmuştur. ${ }^{26}$ Savaş yıllarında Viyana ve Berlin'de açılan Türk resim sanatı sergilerinin başında bulunmuştur. ${ }^{27}$

1920 y1lında Sanayi-i Nefise Mektebinde Belediyecilik ve Şehircilik, Mimarlık Tarihi, Şehircilik derslerini 1940 yılına kadar aralıklarla sürdürmüştür. Aynı süreç içinde Darülbedayi (şehir tiyatrosu) Müdürlüğü ve İstanbul Ticaret Odası Neşriyat Müdürlüğü gibi görevlerde de bulunmuştur. ${ }^{28} 1928$ 'de Ticaret Odası tarafından Türk mallarını Avrupa pazarlarında tanıtmak amacıyla düzenlenen bir geziye başkanlık

24 Arseven, Sanat ve Siyaset Hatıralarım, 48.

25 1911'de Paris'te yayımlanan bir dergide Bréhier Louis bu kitabın iki sayfalık bir tanıtımına yer vermiştir. Bréhier Louis özetle Celal Esad'ın Fransızcayı çok iyi kullanarak İstanbul'u ve Türk mimarisini Fransa'ya çok iyi anlattığını, Türk sanatının kaynağını Orta Asya'ya dayandırdığını dile getirmekte ve kitabın içeriğinden bahsetmektedir. Kitaba övgülerini sıralayan Louis, bu çalışmaya tek bir noktada eleştiri yapmaktadır. O da Rönesans'ta imparatorluğa katkıda bulunan mimarların göz ardı edildiği, Celal Esad'ın padişahların hizmetinde çalışan İtalyan sanatçıların bir listesini ve çalışmalarının kapsamını vermesinin iyi olacağı düşüncesidir. Louis'in burada Osmanlı ya da Anadolu Türk sanatını bir Doğu-Batı sentezine dayandırmak istemesi muhtemeldir. Bréhier Louis, “Djelal-Essad Bey, Constantinople, De Byzance à Stamboul," Journal Des Savants 9 (1911):44-45.

26 Eyice, "Celal Esad Arseven, 1875-1971," 176-177.

27 Savaş yıllarında Osmanlı dış işlerinin sıkça ilgilendiği konu Batılı devletler nezdinde kendini modern gösterebilmek ve böylece dışarıdan ekonomik ve siyasi anlamda yardım sağlayabilmektir. Bu amaçla Celal Esad'dan bu konuda bir rapor hazırlaması istenmiştir. Celal Esad hazırladığı raporda müttefik devletlerin önemli şehirlerinde Osmanlı modernleşmesini gösterebilecek resim sergileri ve konserler verilmesini önermiştir. Rapor kabul edilmiş ve önce Mabeyn-i Hümayun müzik şefi Zeki Bey seksen kişilik bir senfoni orkestrasıyla Beethoven, Wagner, Schubert ve Haydn'ın eserlerinden bir repertuar oluşturulmuştur. Topluluk bir Avrupa turnesi yaparak 1918'de yurda dönmüştür. Resim alanındaysa özellikle askeri konuların işlenmesi istenmiş ve Şişli'de bir atölye kurulmuştur. Ressamlar arasında Türk resminin ünlü isimleri İbrahim Çallı, Feyhaman Duran, Namık İsmail, Hikmet Onat, Sami Yetik ve Ali Sami de bulunmaktadır. Sergi önce Beyoğlu'nda açılmış ardından Celal Esad başkanlı̆̆ında Viyana ve Berlin’e gönderilmişstir. Arseven, Eski Galata ve Binaları, 13.

28 Eyice, “Celal Esad Arseven, 1875-1971," 177. 
etmiş ve aynı yıl buradaki izlenimlerini Seyyar Sergi ve Seyahat Intibaları adlı bir eserde yayımlamışıır. ${ }^{29}$

1920’li yılların sonunda Türk kültürünün kökenleri hakkında önemli çalışmalar yapmış, tarih, antropoloji, dil ve sanat ile Türklerin en eski ve köklü uygarlıklardan biri olduğunu kanttlamak istemiştir. Bu anlamda özellikle İslam öncesi Türk dönemine ait incelemeler yapmış ve İslam ve Türk sanatının farklılıklarını ortaya koymak istemiştir. Böylece Batı'da İslam sanatları olarak adlandırılan Osmanlı ve Anadolu sanatlarını Türk Sanatı adıyla tanıtmanın daha doğru olduğunu ileri sürmüştür. ${ }^{30}$

1930 yılında Atatürk'ün hazırlanmasını istediği Türk Tarihinin Ana Hatları adlı projeye 1932 yılında destek vermiştir. Bu proje için yaptı̆̆ araştırmalar doğrultusunda Türklerde Mimari adlı eserini yazmıştır. ${ }^{31}$ Bunu, Türk ve Arap-İran süsleme sanatları arasındaki farkı göstermek için yazdığı Fransızca Les Arts Décoratifs Turcs ve sonrasında 1943-1952 arasında yayımlanan beş ciltlik Sanat Ansiklopedisi izlemiştir. ${ }^{32}$

Celal Esad 1942'de İstanbul, 1946'da Giresun milletvekili olarak mecliste yer almıştır. 1951'de Gayrimenkul Eski Eserler ve Anitlar Yüksek Kuruluna üye seçilmiştir. İki yıl kurul başkanı olarak çalışmış, 1958'de istifa etmiş ve kurul üyeliğinden ayrılmıştır. ${ }^{33}$

Celal Esad, Cumhuriyet'in ilk yıllarında o dönem etkili olan $O_{z}$ Türkçe akımının etkisiyle, sanat karşılığ kullanılan $A r$ kelimesinden türetilen Arseven soyadını almıştır. ${ }^{34}$ Arseven üç defa evlenmiş, ilk evliliğinden bir kız bir erkek çocuğu olmuş ve 1971 yılında Kadıköy'de yaşamını yitirmiştir. ${ }^{35}$

\section{St. Louis Dünya Fuarı (30 Nisan-1 Aralık 1904) ve Osmanlı Temsiliyeti}

St. Louis Dünya Fuarı, ilk olarak 1903 yılında yapılması planlanan ancak daha geniş katılım için bir sene ertelenerek Amerika Birleşik Devletleri'nde düzenlenmiş üçüncü büyük fuardır. ${ }^{36}$ XIX. yüzyılın bitiminde St. Louis, Missouri eyaletine bağlı, Amerika'nın en büyük dördüncü ve hızla büyüyen şehri durumundadır. St. Louis şeh-

29 Arseven, Sanat ve Siyaset Hattralartm, 22.

30 Kuban Arseven' in bu konuda vardığı sonuçları şu şekilde anlatmaktadır: “Araplarda mübalăğalı bir süs zevki, Iran eserlerinde tezyinî fantezi, Hint te mistisizm ve karışıklık Türk Sanatında ise sadelik, mübalâğadan azadelik, şekillerin ahengi ve mantıkiliği vardı". Bu tantmlamalar sübjektif nitelikte olmakla beraber, farklllıkların ortaya konmast yolunda önemli bir adım." Doğan Kuban, "Celal Esad Arseven ve Türk Sanatı Kavram1," Mimarlk 72 (1969), 18.

31 Arseven, Eski Galata ve Binalart, 15.

32 Arseven, Sanat ve Siyaset Hattralarim, 23.

33 Eyice, "Celal Esad Arseven, 1875-1971," 177.

34 Arseven, Eski Galata ve Binalart, 15.

35 Eyice, "Celal Esad Arseven, 1875-1971," 178.

36 Universal Exposition, St. Louis, U.S.A., 1904: Commemorating the Acquisition of Louisiana Territory: It's Story and Purpose, St. Louis: The Exposition 1904?, erişim 10 Şubat 2019 https://babel.hathitrust.org/cgi/pt ?id=uc1.31175014412988\&view $=1$ up\&seq $=3 \&$ size $=125$. 
ri, kendisine rakip olan Şikago'da 1893'te düzenlenen bir uluslararası serginin başarılı sonuçlarından etkilenmiş ve şehrin 1803 yılında Fransızlardan satın alınmasının 100. yılını kutlamak amacıyla burada da benzer katılımlı bir fuar düzenlenmesi düşünülmüştür. Fikrin sahibi St. Louis eski belediye başkanı ve o sırada Missouri valisi olan David R. Francis'tir. ${ }^{37}$

Fuar alanı için sık ormanlık bir bölge olan Forest Park seçilmiştir. Buradaki ağaçların kesilmesi ve yeni düzenlemesine karşı çıkanlar olsa da yoğun bir çalışma sonucu parkın dönüşümü sağlanmıştır. Kanalizasyon sularının akıtıldığı ve her an sel oluşma riski olan bir derenin 1slahı, yeni alt yapı oluşturulması gibi zor ve pahalı bir süreçte, 15 bin kişilik bir ekip görev almıştır. Toplamda 15 milyon dolar harcanarak 1142 dönümlük bir alan üzerine çeşitli binalar inşa edilmiştir. Fuar binaları bu alan üzerine yelpaze oluşturacak şekilde konumlandırılmış ve yelpazenin en ucuna da sanat binası yerleştirilmiştir. ${ }^{38}$ (G. 3)

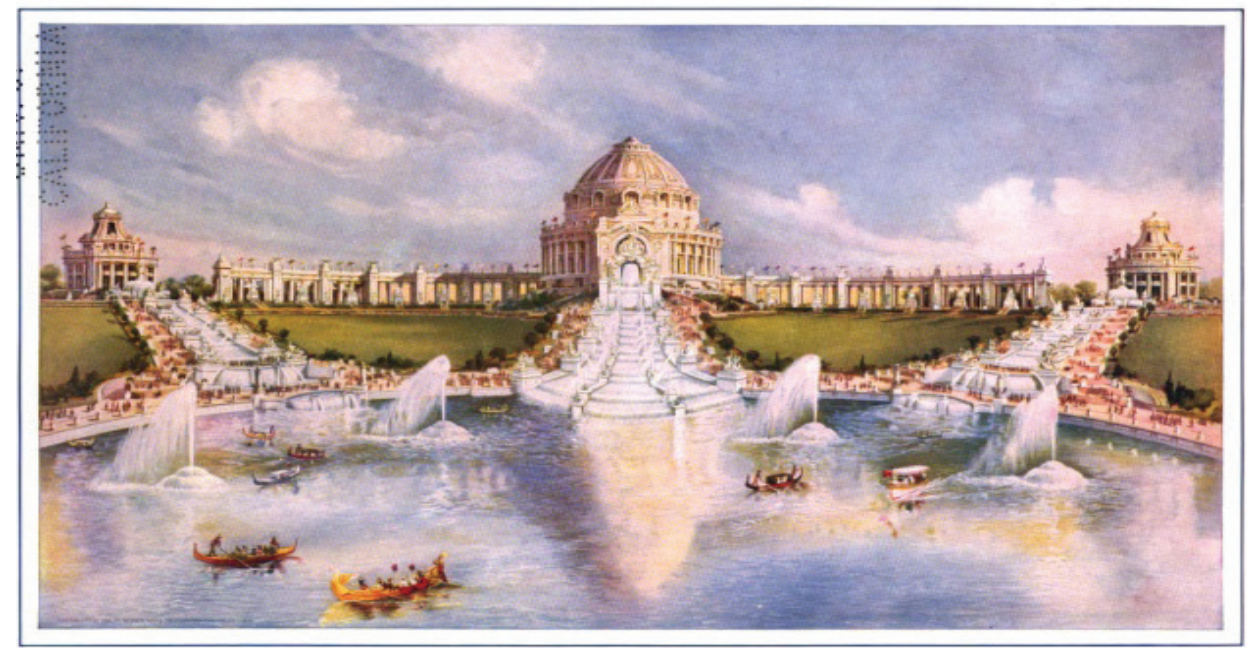

FESTIVAL HALL AND CASCADES.

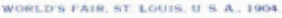

G. 3. Fuar Alanı Merkezi. (Grandeur of the Universal Exposition at St. Louis: 1904) https://babel.hathitrust.org/cgi/pt?id=uc1.c093552783;view=1up;seq=5/ erişim 10.02.2019

Fuarın ana girişi, ağaçlıklı bir yola çıkan ve kuzeydoğu köşesinde bulanan kapısıdır. Fuar, merkezinde peyzaj düzenlemesi olan, yeşil, sulak bir plato etrafında fabrika (üretim) binası, eğitim binası, sosyal bilimler binası, maden ve metalürji binası, çeşitli endüstri binaları, eğitim binası ve elektrikli binalarla çevrili suyolu, makine binaları, ulaşım binası, sanat müzeleri, yönetim binası, ziraat binası, bahçecilik binaları, yaban hayat ve balıkçılık binası, canlı yaşamı pavyonları ve daha birçok binadan oluşmakta-

37 Erik Mattie, World's Fairs (New York: Princeton Architectural Press, 1998), 118.

38 Mattie, World's Fairs, 118. 
dır. ${ }^{39} \mathrm{Bu}$ çağdaş binaların hepsi Beaux-Arts stilinde yapılmıştır. Fuarda 47 dönümlük bir alan Filipin Yerlileri ve Amerikan kolonilerinin buradaki pahalı meyve üretim sergisi için ayrılmıştır. İnşası bir yıla yakın süren fuar alanının geri kalan kısmında yabancı ülke pavyonları yer almıştır. ${ }^{40}$ (G. 4)

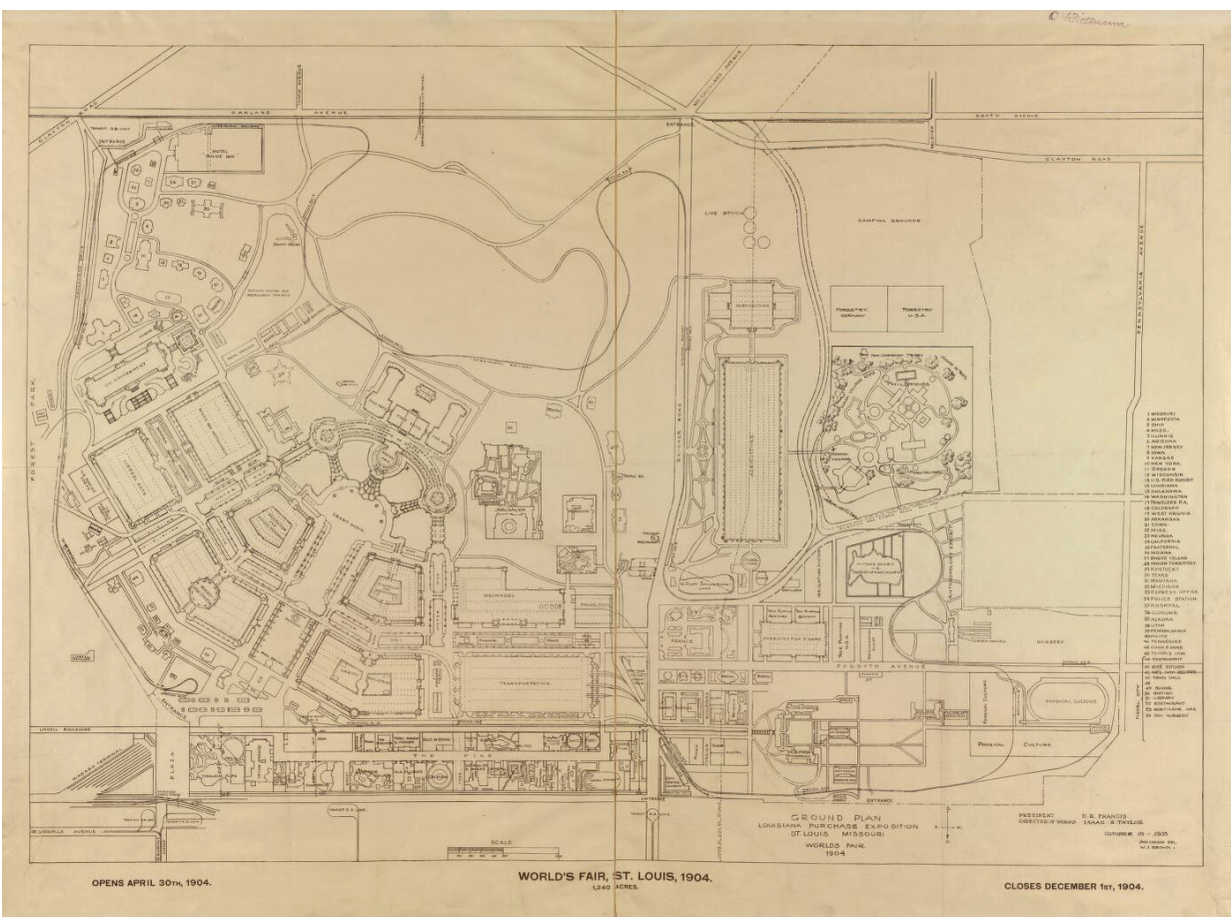

G. 4. St. Louis Fuar alanının planı.

(https://www.loc.gov/resource/g4164s.ct002185/?r=0.436,0.318,1.194,0.431,0/ Erişim 10.02.2019)

Türk pavyonuysa fuar alanının en arkasında Pike olarak adlandırılan ${ }^{41}$ geniş ve uzun bir yolun iki yanına konumlandırılmış Çin ve Eskimo pavyonları arasında Constantinople adıyla yer almaktadır (G. 5). Doğulu ve Batılı pavyonların birlikte yer aldığı bu yol üzerinde İstanbul pavyonunun Sibirya, Çin, Eskimo ile aynı sırada, Kahire'nin ise karşısında konumlandırılıșı dikkat çekicidir.

39 World Fair's Bulletin, May 1903, 13.

40 Mattie, World's Fairs, 120.

41 Bu yol daha önce Şikago'da düzenlenen fuarda bir panayır yeri bulunmasına karşılık olarak düzenlenmiş ve kullanılmıştır. 


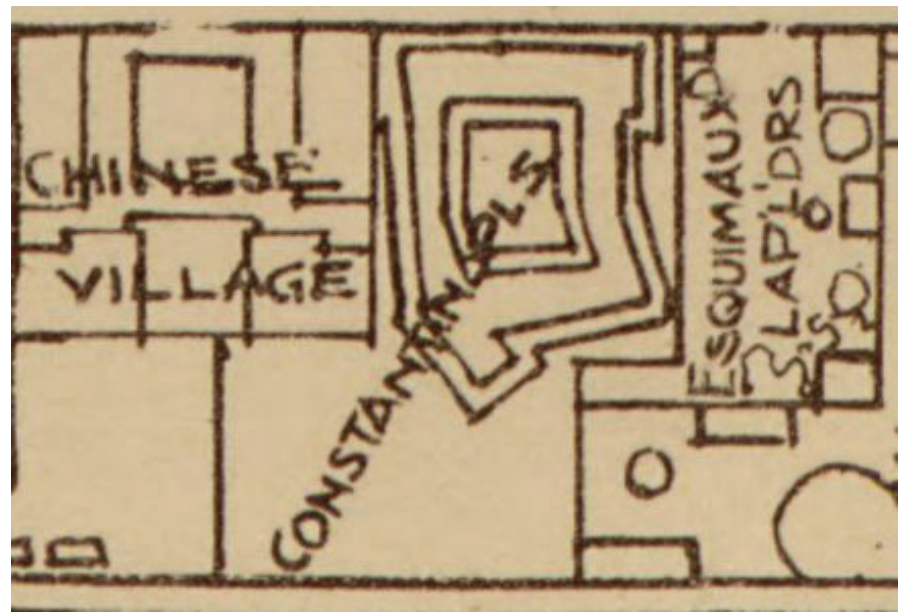

G. 5. St. Louis Fuar alanında İstanbul Pavyonu (G. 4'ten ayrıntı)

Fuarda Türk pavyonuna oldukça küçük bir yer ayrıldığg görülmektedir ve kareye yakın bir plana sahip alan seçilebilmektedir. ${ }^{42}$ Bunun nedeni muhtemelen fuara Osmanlı katılımının düşük olmasıdır. Cumhurbaşkanlığı Osmanlı Arşıivi’nde fuara ilişkin elde edilen 24 Recep 1321/16 Ekim 1903 tarihli bazı belgelerin padişahın katılımın sağlanması yönünde çıkarttığı mazbatalar olduğu görülmektedir. ${ }^{43} 19$ Recep 1321/11 Ekim 1903 bazı belgelerde ise yine katılımın sağlanması için gereken yardımın yapılması istendiği ve fuar fahri komiserliğine Washington Sefiri Şekib Bey’in tayin edildiği anlaşılmaktadır. ${ }^{44}$

Öte yandan bazı belgelerde birtakım özel girişimcilerin bu dönem İslam dünyasının lideri olma konumunu kullanırcasına padişahtan fuarla ilgili destek istediği anlaşılmaktadır. ${ }^{45}$ Buna göre 30 Aralık 1903 'te banker olan Bay Konta adında bir kişi sergiye birlikte katılmak istediğini sultana bildiren bir mektup yazmıştır. Bu kişi sergide Kudüs reprodüksiyonu ve Osmanlı pavyonu bulundurulmasını önermektedir ve en önemlisi de Halife Ömer Camii'nin tam bir canlandırılmasının yapılmasını istemektedir. Bunun karşılığında Osmanlı sergisine ait bütün ürünleri taşımayı, Hicaz demiryolu için bağış toplamayı ve bir Amerikan tersanesinde imal edilmekte olan Mecidiye Kruvazörü'nü suya indirip mürettebatını şirket hesabına kaydettirmeyi teklif etmektedir. Ayrıca camiye sultanın kendisinin imam ve müezzin atamasını da önermektedir. Eğer sultan kendisine sunulan teklifi kabul etmezse onu Misır, Tunus, Fas

42 Fuara ilişkin çok sayıda kaynak olmasına ve bu kaynaklarda hemen hemen bütün ülkelerin sergi ve pavyonlarının fotoğrafları bulunmasına rağmen Osmanlı ya da Constantinopolis pavyonu hakkında bir görüntüye ulaşılamamıştır. Hatta aynı şekilde fuar alanını gösteren pek çok plan ya da harita bulunurken yalnızca bu kaynakta Constantinopolis pavyonunun yerine rastlanabilmiştir.

43 BOA, İ.HR., 386-7.

44 BOA, Y. PRK., BŞK. 71-6.

45 Selim Deringil, İktidarın Sembolleri ve İdeoloji-II. Abdülhamid Dönemi, çev. Gül Çağalı Güven (İstanbul: Doğan Kitap Yayınları, 2014), 179. 
ve Cezayir hükümetlerinden yardım istemekle tehdit etmektedir. Bu yardım isteme durumu, İslam dünyasının lideri olan bir ülkenin prestijini sarsmak anlamına gelmektedir. Osmanlı hariciyesi, sunulan tekliflerin avantaj sağladığına inanarak yabancı ülkelerin egemenliğindeki rakip Müslüman devletlere fırsat vermenin yanlış olduğu kanısında olsa da bu tekliflerin ne kadarına olumlu cevap verildiği kesin değildir. Ancak fuara gönderilen bütün mallara gümrük vergisinden muafiyet verilmesi bazı koşulların kabul edildiğini göstermektedir. ${ }^{46}$

Bu olaydan aylar öncesinde ise zaten fuara katılabilmek için bir Türk pavyonu projesi ve sergileri hazırlanmıştır. Ancak bu hazırlık yalnızca İstanbul'u kapsamaktadır. Celal Esad 1903 senesinin başında Sanayi-i Nefise'de çalışan üç Rum ressamla tanışmıştır. Bu ressamlar Beyoğlu'nda o dönem bulunması çok zor olan kadın modeller etrafinda toplanıp resim yapılan bir gece atölyesi oluşturmuştur. Celal Esad bu atölyede bulunduğu sırada Amerikalı Pangalo isimli biriyle tanışmıştır. Pangalo, ona Amerika'daki St. Louis şehrinde açılacak olan sergiye eski İstanbul mahalleleri ve çarşısı konulu bir proje hazırlamasını ve yarışmaya katılmasını önermiş̧ir. Celal Esad'ın bir ay kadar kısa bir süre içinde hazırladığı projesi kabul görmüş ve Amerika'dan kendisine fuara katılmak üzere bir davet gelmiştir. ${ }^{47}$ Ancak o dönem yurtdışına çıkışlardaki bazı kısıtlamalar sebebiyle Amerika'ya gidememiştir. ${ }^{48}$

1903 'te Amerika'da yayımlanan Dünya Fuar Bülteni Haziran sayısında bu konuya dair iki sayfalık bir yazıya yer verilmiştir. ${ }^{49}$ Yazıda fuarın en ilgi çeken sunumlarından birinin Kapalıçarşı olduğu belirtilmekte ve çarşının İstanbul'daki yeri ve önemini vurgulanmaktadır. Ardından çarşının konumu verilmekte ve mimari yapısı anlatılmaktadır. Yazıda Kapalıçarşı kolonlar ve tonozlarla birbirine açılan bir labirente benzetilmektedir. Tahmini olarak 300 dükkândan oluştuğu ve 240'ının farklı iş yerlerine ait olduğu anlatılmaktadır. Yapının tarihinin Bizans dönemine kadar uzandığı, günümüze gelene kadar çok sayıda onarım geçirdiği ve en son onarımın 1894'teki korkunç depremden sonra yapıldığı belirtilmektedir. Çarşı, Oryantal ya da Türk mimari üslubundadır şeklinde tanımlanmaktadır. Ardından seçici kurulun Kapalıçarşı'nın sergilenecek bölümünü kararlaştırılırken zorlandığından ve Nur-u Osmaniye olarak anılan bir cami tarafındaki kapının seçildiği belirtilmekte ve doğudan batıya düz bir şekilde uzanan Kalpakçılar Caddesi ve çarşıya ait bazı sokak görünümlerine ait 11 adet çizimden bahsedilmektedir. Çarşının reprodüksiyonu yapılırken bütün caddelerin düzgünce birbirine bağlanarak ve en ufak detayları bile atlamadan yeniden üretildiği, sergi için ayrılan alanın küçük olması dolayısıyla sokakların kısaltılmasına rağmen perspektifin çok başarılı şekilde uygulandığı belirtilmektedir. Ardından Celal Esad

46 Deringil, İktidarın Sembolleri ve İdeoloji-II. Abdülhamid Dönemi, 180.

47 Bu davet mektubu için bkz. Bülent Özer, "Celal Esad Arseven,” Mimarlık 72 (1969), 23.

48 Arseven, Sanat ve Siyaset Hatıralarım, 48.

49 World Fair's Bulletin, July 1903. 
hakkında kişisel bilgiler verilerek eserlerinden övgüyle bahsedilmektedir. Devam eden bölümde Celal Bey’in Pangalo'nun teklifini kabul edip fuar için çizimleri hazırlaması Pangalo için bir şans olarak görülmektedir. Yazıya göre Celal Bey fuarla ilgili bir açıklamasında, bu işi Türk imajının yanlış anlatılması ve tanıtılmasını önlemek, sultanın itibarını arttırmak istediği için kabul ettiğini söylemiştir. Yazı, Pangalo'nun Mısır-St. Louis sergi şirketinin sahibi olduğu ve onun Eames\&Young adlı bir firmayla Celal Bey'in çizimlerini sergilemek ve reprodüksiyonunu yapmak üzere anlaşma sağladiğını belirterek sonlanmaktadır. ${ }^{50}$

1913 senesinde St. Louis fuarı hakkında yayımlanmış bir kitaptaysa buradaki bilgiler kısmen tekrarlanmakta ve Kahire ve İstanbul reprodüksiyonunu yapan şirketin aynı olduğu belirtilmektedir. Yazının sonunda çarşının fuar alanındaki sergisinde Türk esnaflar ve ürünleriyle gerçek bir sokak gibi canlandırıldığından bahsedilmektedir. ${ }^{51}$

\section{Bugün İstanbul Büyükşehir Belediyesi Atatürk Kitaplı̆̆ı'nda Celal Esad Arseven'in} Kapalıçarşı'ya ait 11 adet sokak, bazı Türk evi bulunan sokak ve cephe çizimlerini de içeren toplamda 14 adet çizimine ulaşılabilmektedir. Üzerindeki Romen rakamların-

50 St. Louis Fuarı ve Celal Esad'ın çizimlerinden Cephanecigil'in 2009'da tamamlanmış doktora tezinde kısaca bahsedilmektedir. Cephanecigil konuyu "Celal Esad Bey bu projesinin resimlerinin hakkındaki bir yazı ile birlikte World"s Fair Bulletin-St Louis"in Temmuz 1903 sayısında yayınlandığını belirtmektedir. Ancak bu belirtilen yayında Celal Esad Bey'in çizimleri ya da inşa edilmiş projeye ilişkin görünümler yer almamaktadır. Metindeki ifadeye göre oldukça küçük bir alanda Kapalıçarşı 'nın Nurosmaniye kapısı ve Kalpakçılar Caddesi ile birlikte toplam 11 caddesi, bunun yanı sıra çarşının dışından bir sokağın canlandırıldı̆̆g bir rekonstrüksiyon yapılmıştır. Metne eşlik eden görseller ise projenin değil Sébah-Joailler imzalı Kapalıçarşı görünümleri ile Celal Esad Bey'in kendi fotoğrafidır. Metinde Celal Esad Bey'den de bahsedilmiş, eğitimi ve görevine değinildikten sonra kendisinin Türkiye'de sanatın gelişimine büyük katkısı olan bir kişi ve önde gelen sanat eleştirmenlerinden biri olduğu dile getirilmiştir. Celal Esad Bey'in bu projeyi yapmayı kabul etmesinin daha önceki sergilerde olduğu gibi vatanının yanlış temsil edilmesini önlemek maksatl olduğu ayrıca ifade edilmiştir. Bu makalenin dışında, Celal Esad'ın söz konusu sergi için yaptığı çalışmaya dair bilinebilen tek görsel malzeme yazarın 1928 tarihli Türk Sanatı kitabında yer alan “Türk mahallesi”" çizimidir. ” şeklinde aktarmaktadır. Bkz. V. Gül Cephanecigil, "Geç Osmanlı ve Erken Cumhuriyet Dönemlerinde Mimarlık Tarihi İlgisi ve Türk Eksenli Milliyetçilik (1873-1930)" (Doktora Tezi, İstanbul Teknik Üniversitesi, 2009), 96.

51 Constantinople on the Pike was operated by the same company which reproduced Cairo. It introduced a new form of attraction in a faithful reproduction of the bazaars of Stamboul. The architectural sketches of the bazaars were drawn by Djelal Bey Ben Essad. One of the best art critics in Turkey, aide-de-camp to the sultan and son of the late Marshal Essad Pasha. The bazaars of Stamboul took in the whole quarter of Constantinople along the heights lying between the Golden Horn and the Sea of Marmora in the vicinity of the old forum of Theodosius. The bazaars were a labyrinth of narrow streets all under covered arcades supported by columns of different shapes. The buildings had a ground floor and very few had a second story. It is estimated that the bazaars contained over three thousand stores. Eleven sections of the bazaars were reproduced at St. Louis, and the gate selected as the entrance was that of the mosque of Nourl Osmanieh. It led to a replica of Kalpakdjilar djadessi or avenue running in a straight line from east to west to the extremity of the bazaars. A typical Turkish street was shown outside of the bazaars. Each street bore its proper relation to the other streets and the minutest details of the architecture were imitated. Notwithstanding the shortening of the streets to meet the requirements of the allotted space the difficulty of preserving perspective effects was accomplished to an astonishing degree. The bazaars were filled with Turkish merchants and their wares and illustrated the street life in that section of Constantinople. David Rowland Francis, The Universal Exposition of 1904, (St. Louis 1913), 598, erişim 10 Şubat 2019 https://babel.hathitrust.org/cgi/pt?id=mdp.39015010951427\&view=1up\&seq $=9$ 
dan çizimlerin 15 adet olduğu anlaşılmaktadır. Bunlardan XIII numaralı ve muhtemelen bir ev ya da evlerin bulunduğu sokak görünümü içeren çizime ulaşılamamıştır. Çizimler esas alınarak Kapalıçarşı'nın bir küçük taklidi yapılmış ve inşa edilen bu reprodüksiyon Türk ya da fuardaki adıyla İstanbul pavyonunu oluşturmuş ve söz konusu çizimler bu pavyonda sergilenmiştir. (G. 6)

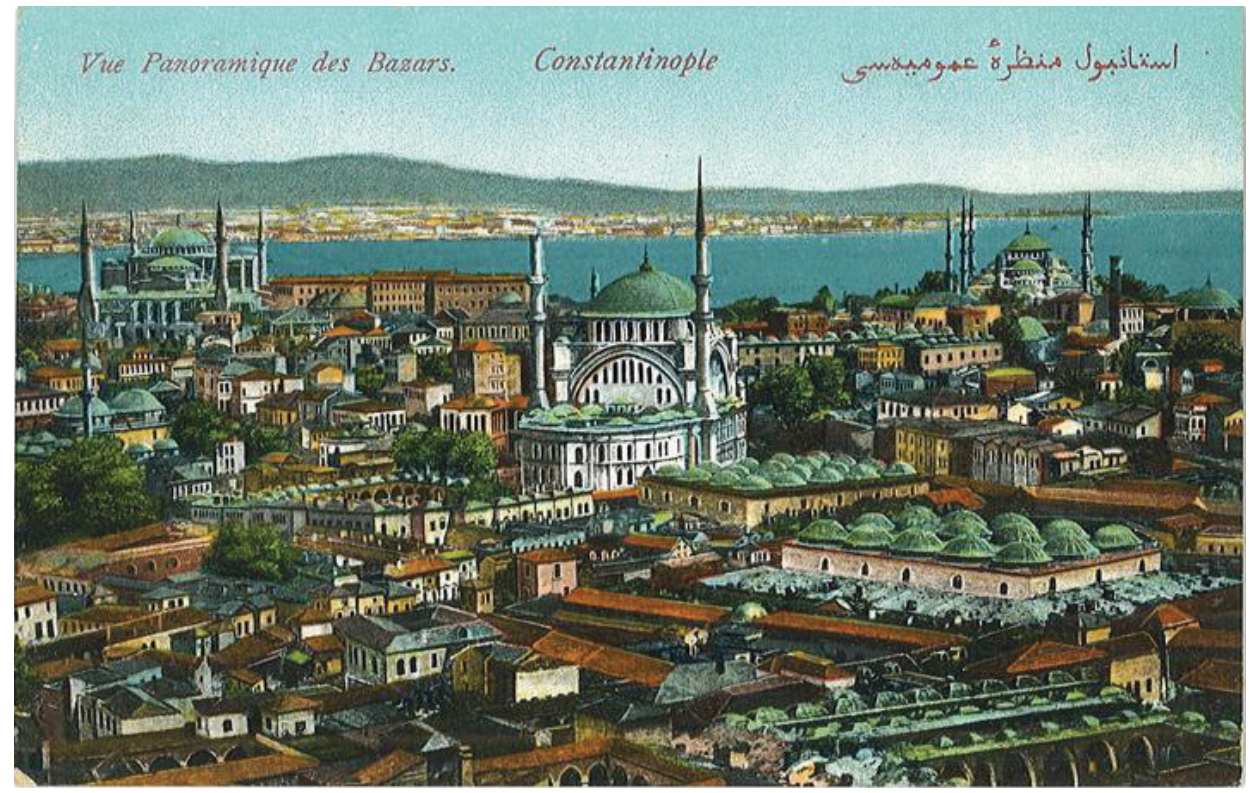

G. 6. Bir Kartpostalda Beyazıt'tan Nur-u Osmaniye'ye doğru Kapalıçarșı'nın sergilendiği bölüm. (Kaynak: https://archnet.org/media_contents/62098/ erişim 07.03.2019)

Celal Esad imzalı ve yine kendisinin, üzerinde St. Louis fuarı için hazırlanan projeye ait olduğunu belirttiği çizimler incelendiğinde, sergilenen bölümün gerçeğinden farklı olduğu anlaşılmaktadır. Sanatçının I numaralı çizimi Kapalıçarşı'nın sergilenecek bölümüne ait plandır. Arseven'in daha önce bahsedildiği gibi sergi için büyük bölümü Kalpakçılar çarşısına ayırdığı görülmektedir. Bugünkü planlarla karşılaştırıldığında aynı isimli caddenin hemen arkasındaki dükkân ve depoların küçük ya da kısaltılmış şekilde çizildiği anlaşılmaktadır. Caddenin güneybatısında bulunan ve planda depo olarak adlandırılmış olan Sandal Bedesteni'nin gerçek plan üzerinde 20 kubbesi olduğu görülmektedir. (G. 7) Arseven'in çizimindeyse bu sayı 6'dır. (G. 8) Diğer dükkân ve sokaklar da buna benzer șekilde gösterilmiștir. 


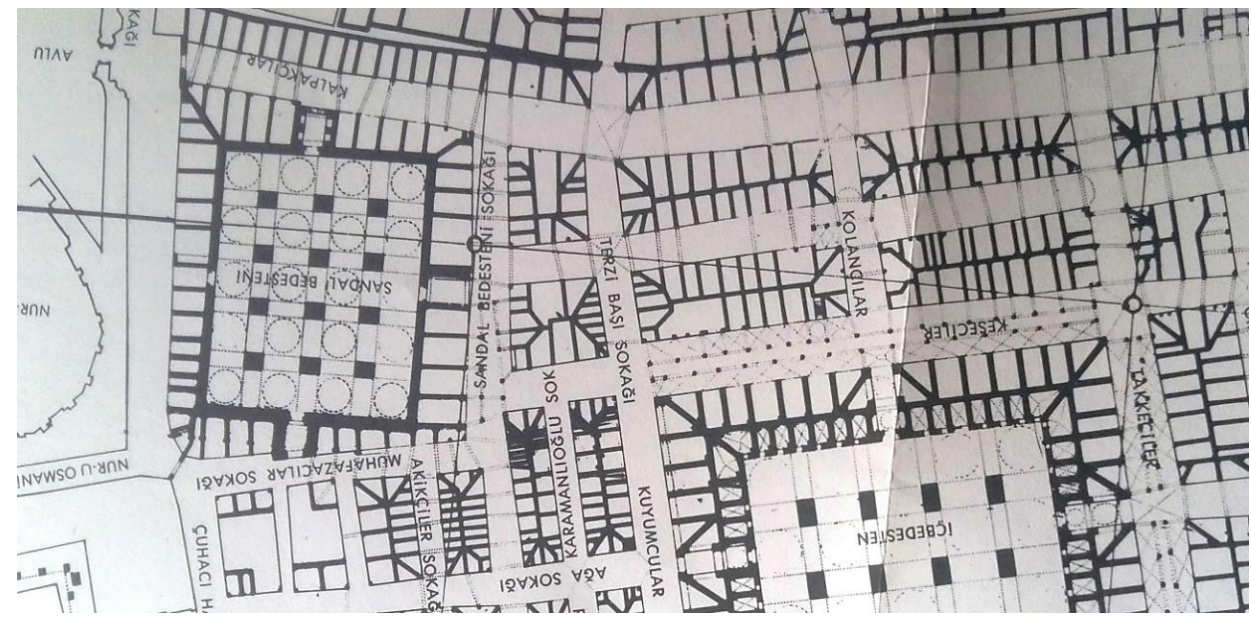

G. 7. Kapalıçarşı'nın St. Louis Fuarında sergilenen kısmının Planı. (Çelik Gülersoy, Story of the Grand Bazaar, 1990)

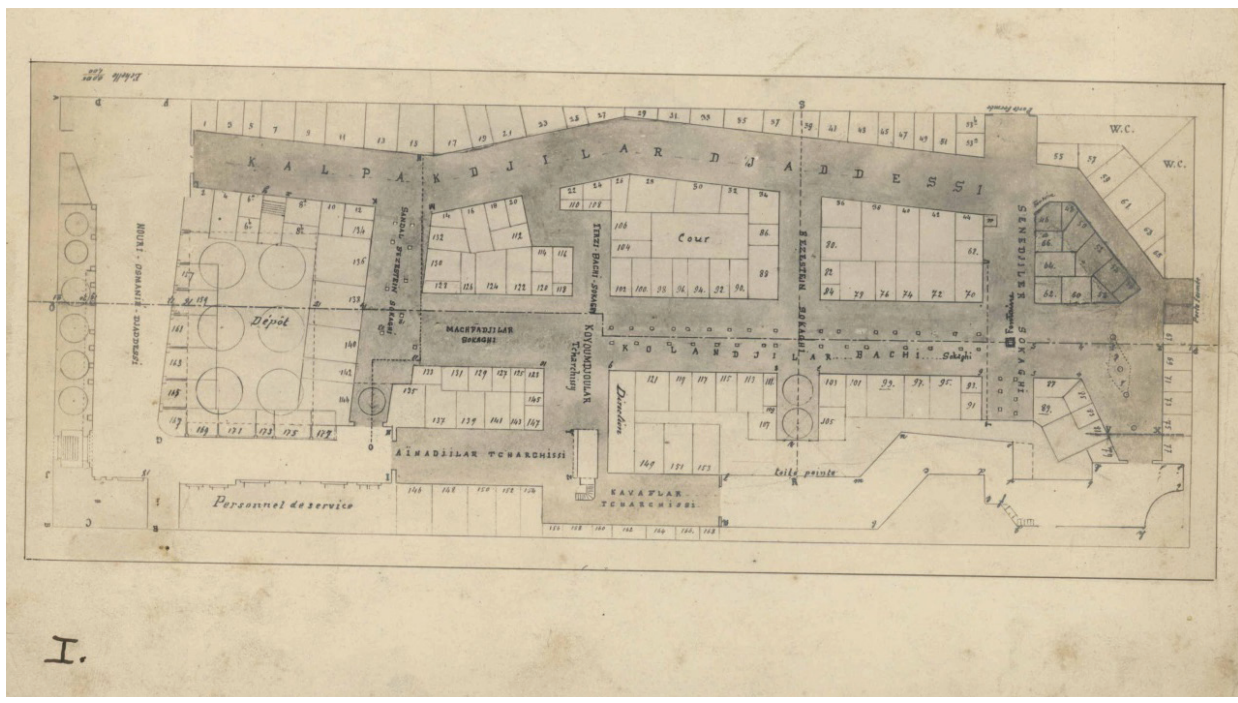

G. 8. Kalpakçılar ve Nur-u Osmaniye caddeleriyle Kavaflar ve Aynacılar çarşıları ve civarı haritasının fotoğrafıdır. (IBBB Atatürk Kitaplığı)

II ve VI. çizimler, çarşının dışarıdan görünümü yani cephe çizimleridir. Bugün tanınması oldukça güç olan bu cepheler en ufak detayıyla verilmiştir. İçlerinden tanınabilir durumda olanlar çarşı girişleridir. (G. 9-G. 13) Bunlardan 1894 depremi sonrasında çarşının ana caddesi olan Nur-u Osmaniye ile Beyazıt arasında uzanan Kalpakçılar Caddesi'nin iki ucuna yerleştirilenler, Sultan II. Abdülhamid zamanında yaygınlaşan Türk neo-klasik üslubunda yapılmıştır. Nur-u Osmaniye tarafında bulunan ve fuarda reprodüksiyonu yapılacak olan kapının mukarnaslı bir saçağı ve altında bir sivri kemeri vardır. Kemer alınlığı içinde devletin son döneminde her resmi bina- 
ya konulan bir Osmanlı arması yer almaktadır. Armanın altında Hattat Sami Efendi tarafından yazılmış onarım kitabesi bulunmaktadır. ${ }^{52}$ Çizimler içerisinde 5 kapı daha görülmekle birlikte bunlardan ikisi aynıdır. Renkli taşla oluşturulmuş yuvarlak kemerli ve ortasından zincir sarkan bu kapı, farklı iki cephe üzerinde gösterilmektedir. Ayrıca mukarnas kavsaralı klasik üslupta bir kapı, sivri kemerli ve harabe bir kapı ile yine renkli taşlarla oluşturulmuş basık kemerli bir kapının daha çizimi vardır. Bunlar çarşının farklı girişleri olmalıdır. Mukarnas kavsaralı klasik Türk mimari üslubunda olan kapı yine klasik mimariyi yansıtan bir binanın cephesinin ucunda gösterilmektedir. Bu yapı cephe kurgusu itibariyle Beyazıd Camii'ni yansıtmaktadır. Ancak 6 pencerenin ortasında bulunması gereken kapı en sağdadır. Sol uçtaysa başka bir kapı bulunmaktadır. Sanatçının burada çarşının Beyazıd tarafını yansıtmak istemiş olması muhtemeldir. Daha önce neo-klasik üslupta yapılmış Nur-u Osmaniye kapısının bir benzeri ancak daha sadesi olan, çarşının Beyazıd kapısı yerine Türk mimarisinin klasik üslubundan örnek sunulmak istenmiş olabilir. Çizimlerin içinde göze çarpan diğer bir unsursa sebil ve çeşmedir. Bugün Kapalıçarşı içinde ve civarında burada gösterildiği şekliyle bir sebil ve çeşmeye rastlanmamaktadır. O halde çeşme ve sebilin Celal Esad Arseven tarafından karakteristik özellikler taşıyan ve idealize edilmiş mimari örnekler olarak çarşıdan bağımsız ya da çarşıya ait unsurlar gibi sunulması olasıdır.

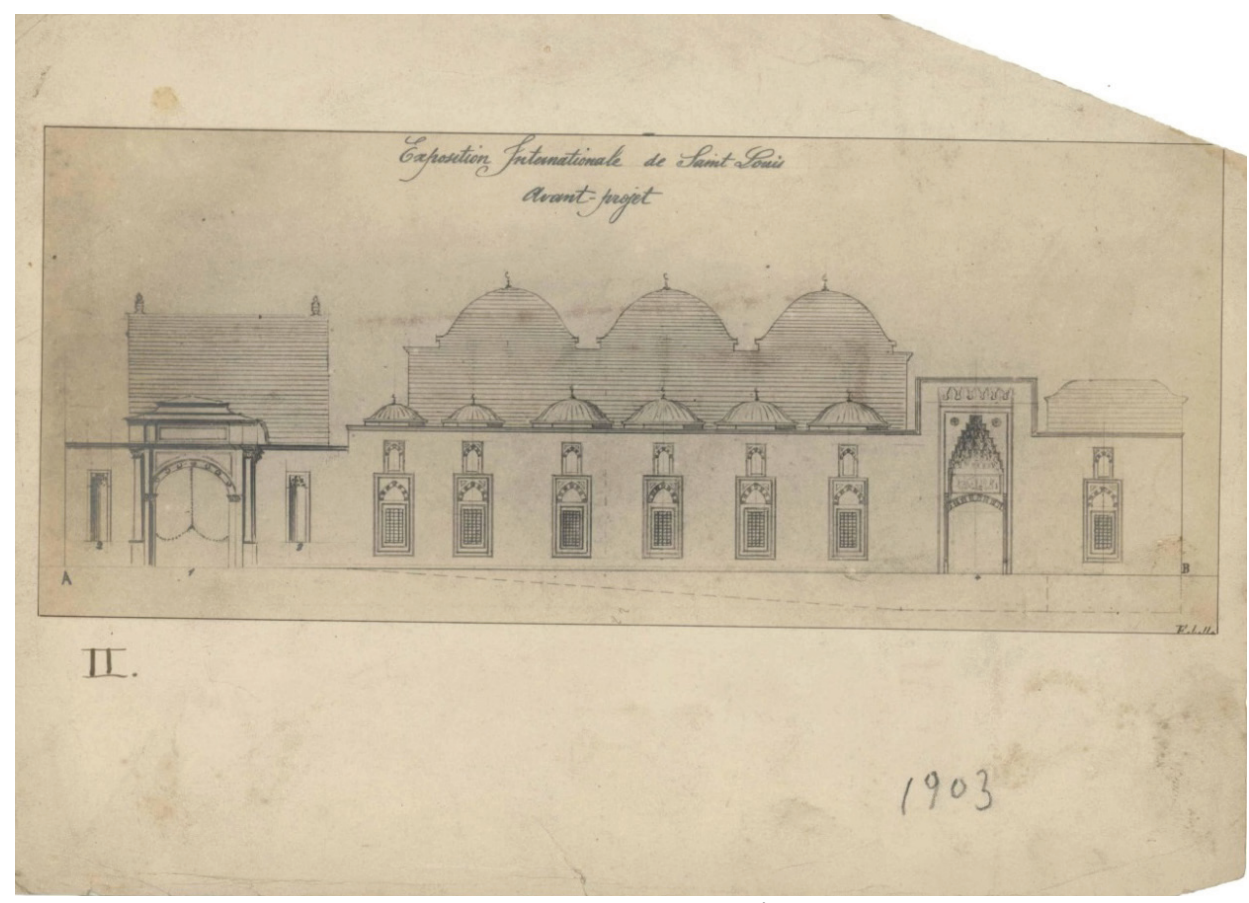

G. 9. Kapalıçarşı'da bir sokak görünümü. (IBB Atatürk Kitaplığı)

52 Semavi Eyice, “Büyük Çarş1,” Türkiye Diyanet Vakfi İslam Ansiklopedisi 6 (1992), 509-513. 


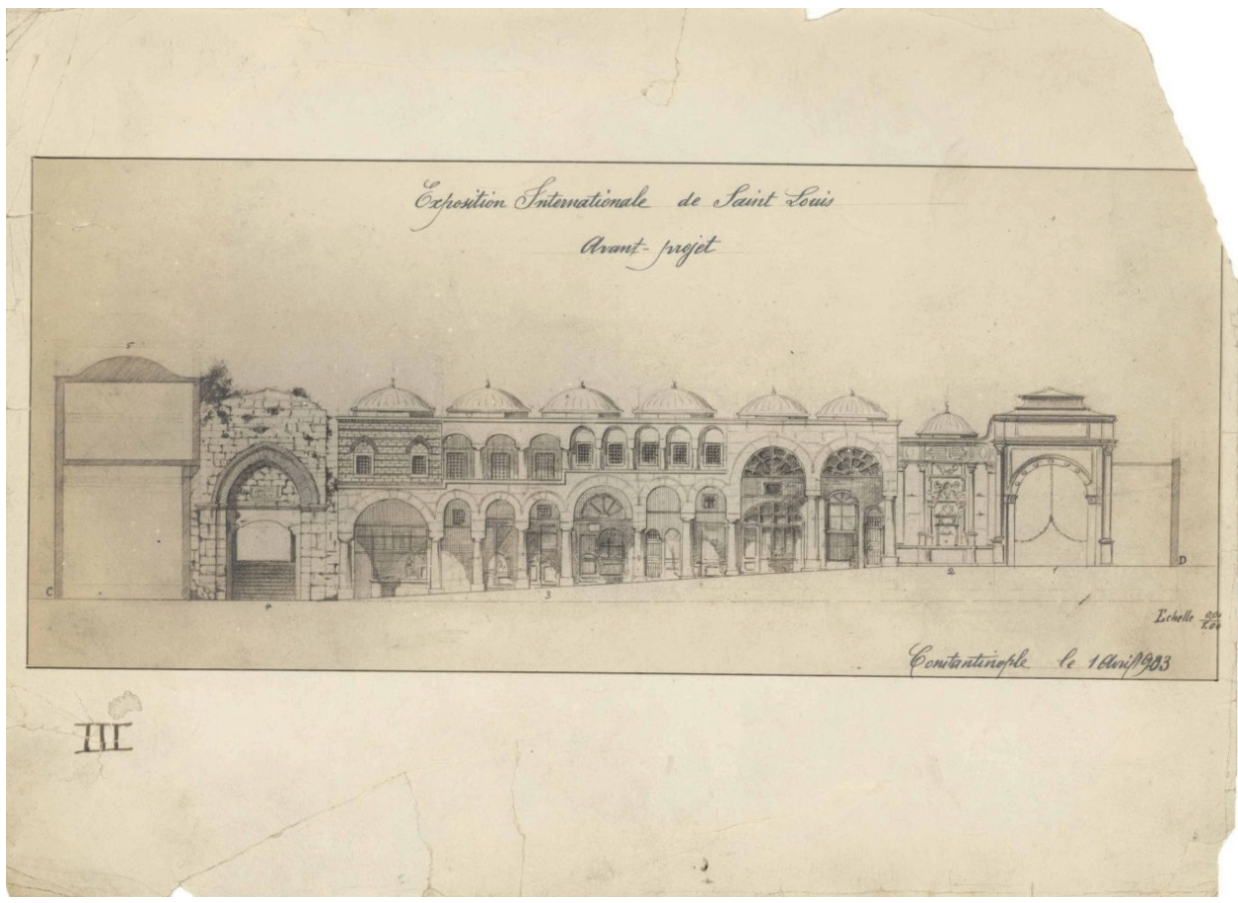

G. 10. Kapalıçarşı'da bir sokak ve dükkânların görünümü. (İBB Atatürk Kitaplığı)

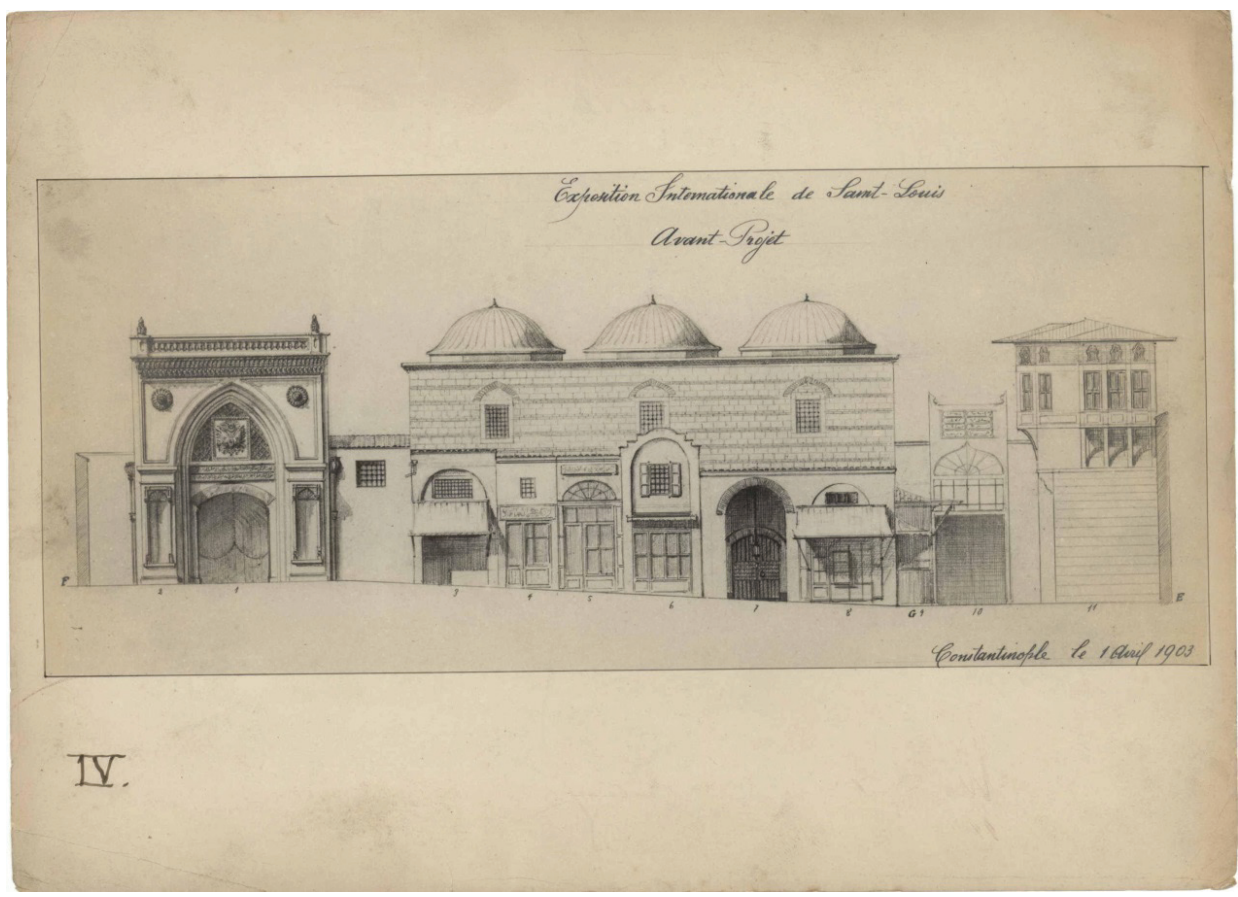

G. 11. Kapalıçarşı'da bir sokak görünümü. (İBB Atatürk Kitaplığı) 


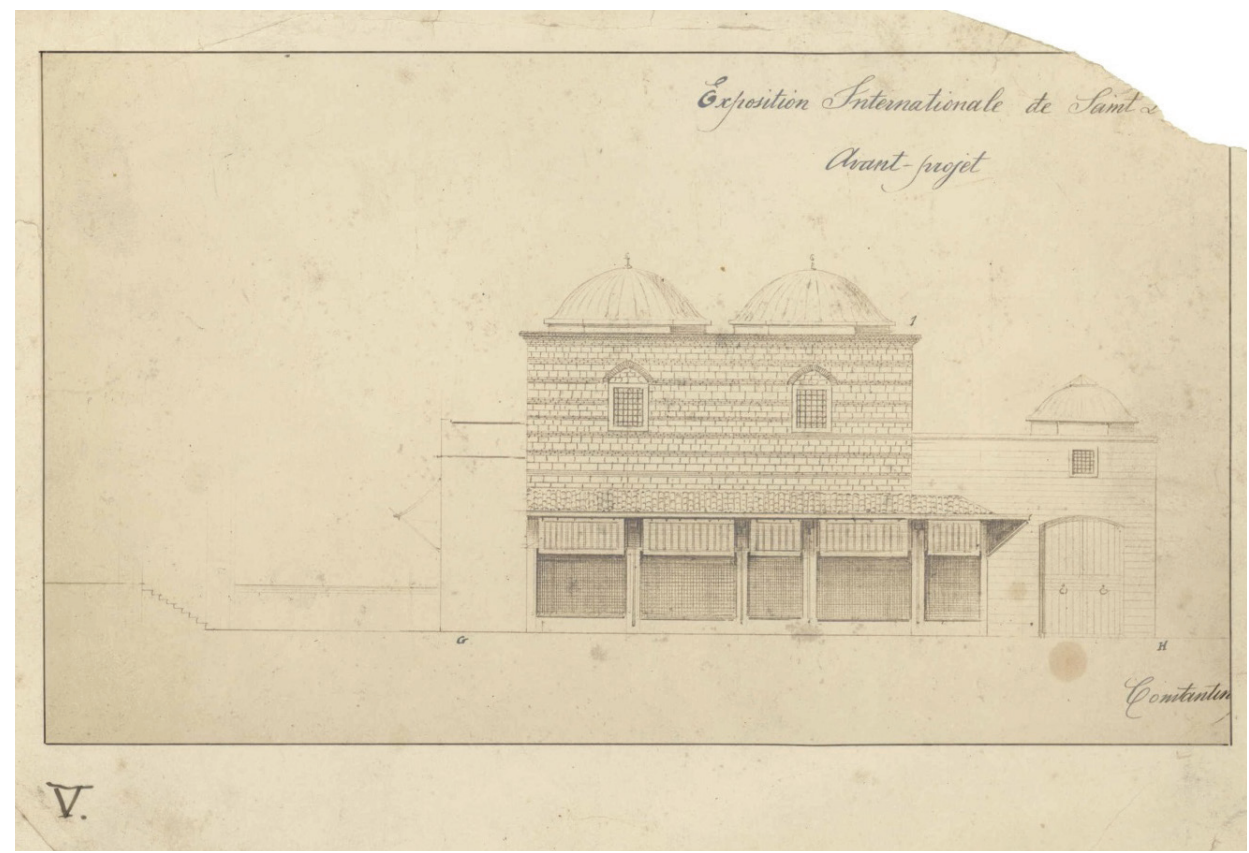

G. 12. Kapalıçarşı' dan bir hanın görünümü. (İBB Atatürk Kitaplığı)

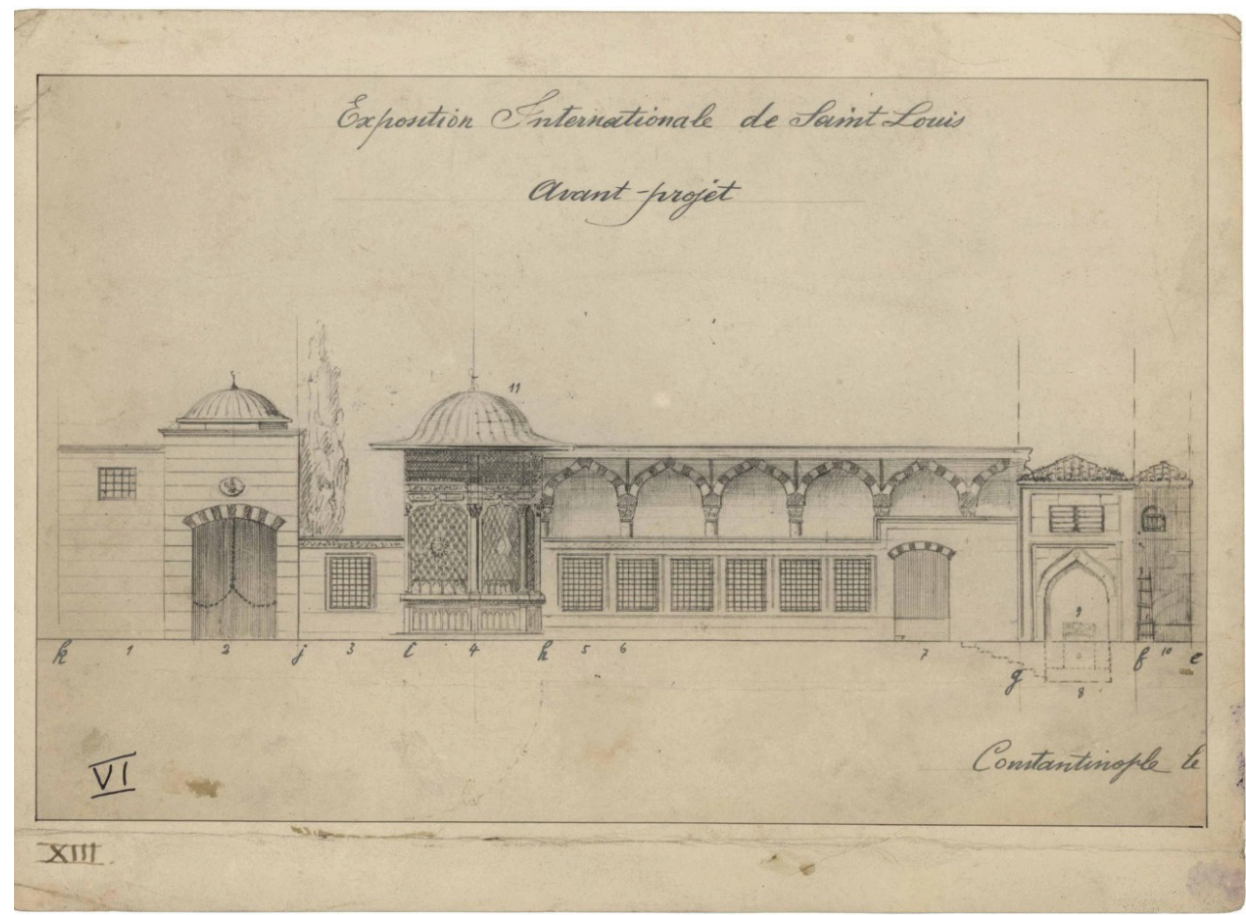

G. 13. Kapalıçarşı civarında bir sokak görünümü. (İBB Atatürk Kitaplığı) 
Çizimlerin yapıldığı günden bugüne çarşı birtakım değişiklikler ve onarımlar geçirmiş ve Celal Esad'ın çizimleri yaptığı tarihten sonra da iki büyük yangın görmüştür. Bunlardan ilki 9 Eylül 1943 gecesi çıkmış, birçok han ve dükkân yangından etkilenmiştir. Bu yangından 11 yıl sonra 26 Kasım 1954 gecesi çarşı tekrar bir yangın geçirmiş, bu sefer Kalpakçılar Caddesi üzerinde başlayan yangın Fesçiler, Yorgancılar, Elbiseciler, Yağlıkçılar sokaklarını tamamen, Örücüler, Kavaflar, Parçacılar sokaklarınıysa kısmen yakmıştır. Bu yangında Kapalıçarşı'nın beşte ikisi harap olmuş, onarımı ise beş yıl sürmüştür. ${ }^{53} \mathrm{Bu}$ nedenle söz konusu çizimleri bugünkü Kapalıçarşı görünümleriyle açılamak oldukça zordur.

VII ve XI. çizimler Kapalıçarşı içinin çeşitli açılardan kesitlerini içermektedir. Bu beş değişik kesitte çoğu zaman aynı mekânın kotu, yönü ve kapsamı değişik şekilde sunulmuştur. Çarşının çeşitli açılardan gösterildiği bu beş şeklin sonuncusunda soğan kubbesi ve üçlü at nalı kemer açıklığıyla bir de köşk mescit çizimi yer almıştır. (G. 14-G. 18)

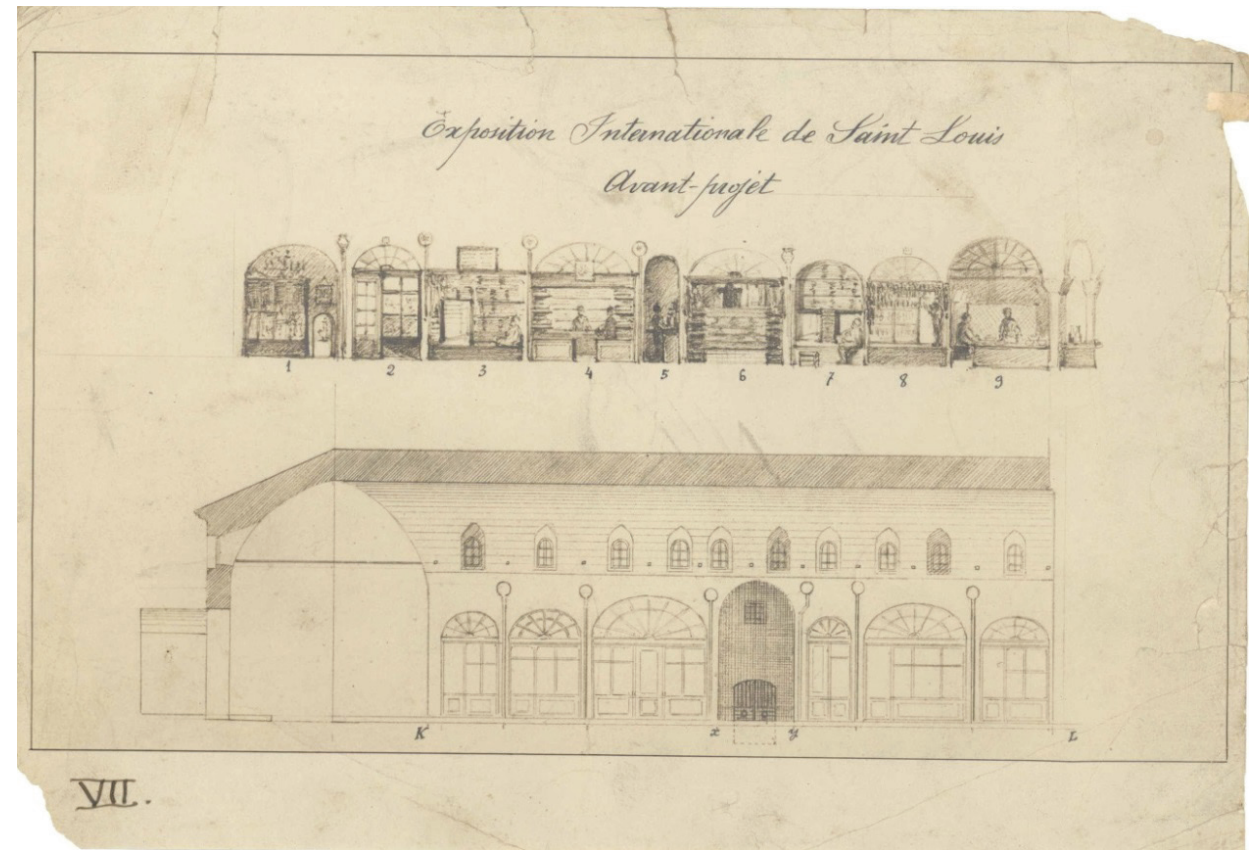

G. 14. Kapalıçarşı dükkânlarını gösteren kesit ve cephe çizimi. (İBB Atatürk Kitaplığı) 


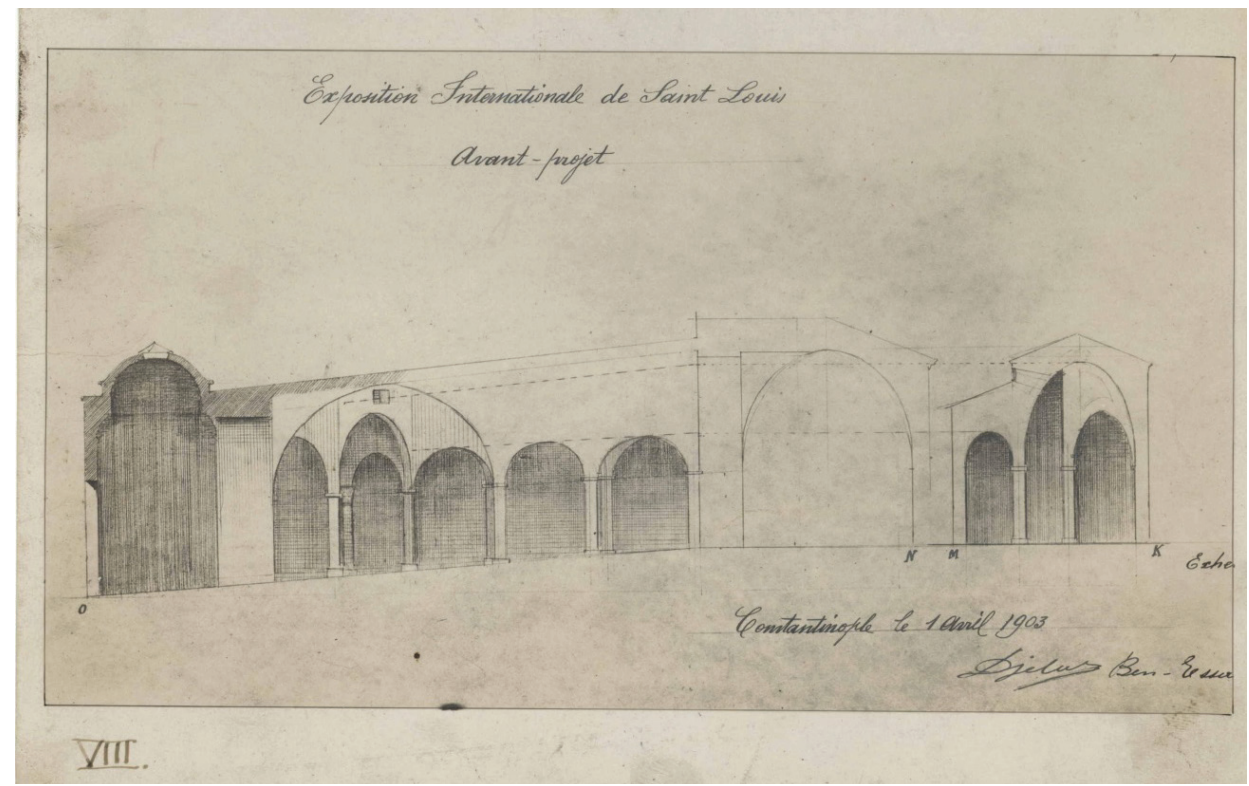

G. 15. Kapalıçarşı'da muhtemelen Kalpakçılar Çarşısı'na ait kesitler (İBB Atatürk Kitaplı̆̆

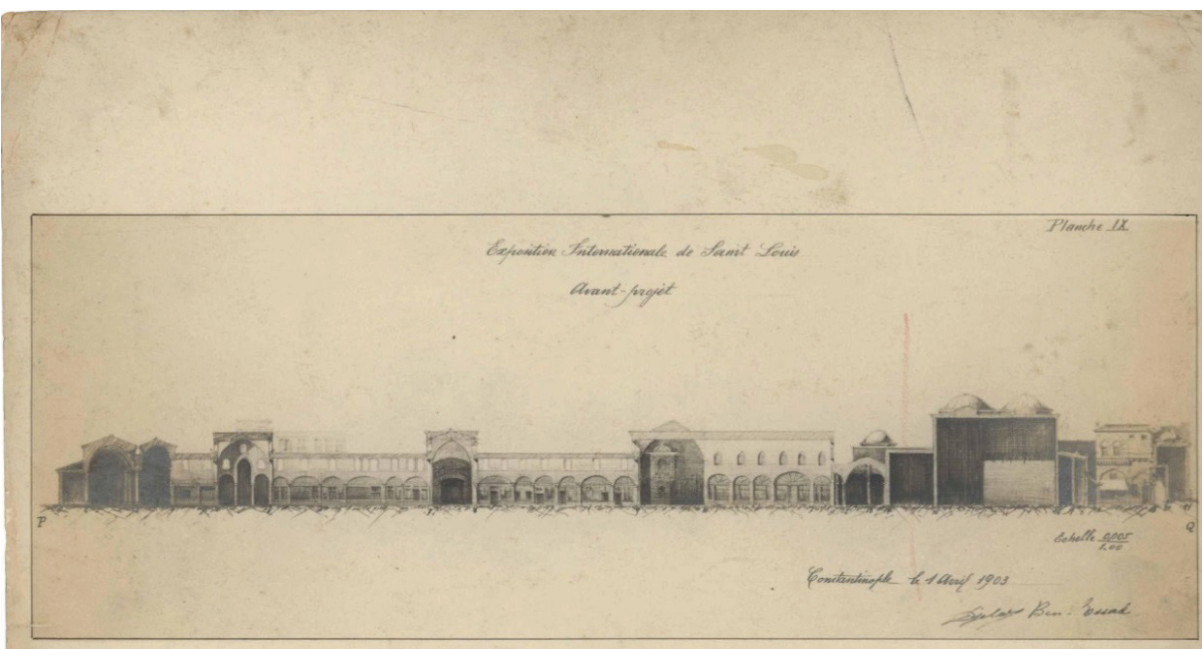

IX.

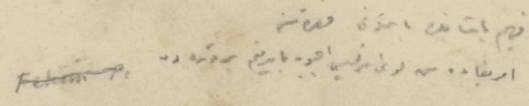

G. 16. Kapalıçarşı'nın çeşitli bölümlerine ait kesitler (İBB Atatürk Kitaplığı) 


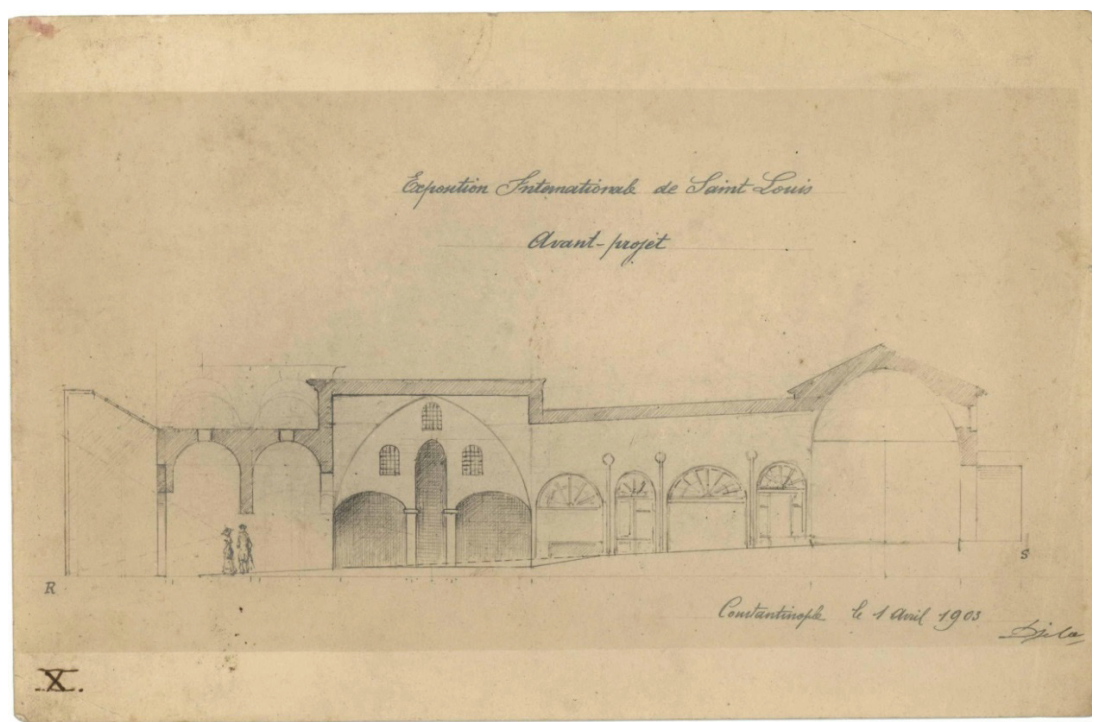

G. 17. Kapalıçarşı'da muhtemelen Kalpakçılar Çarşısı'na ait kesitler (İBB Atatürk Kitaplığı)

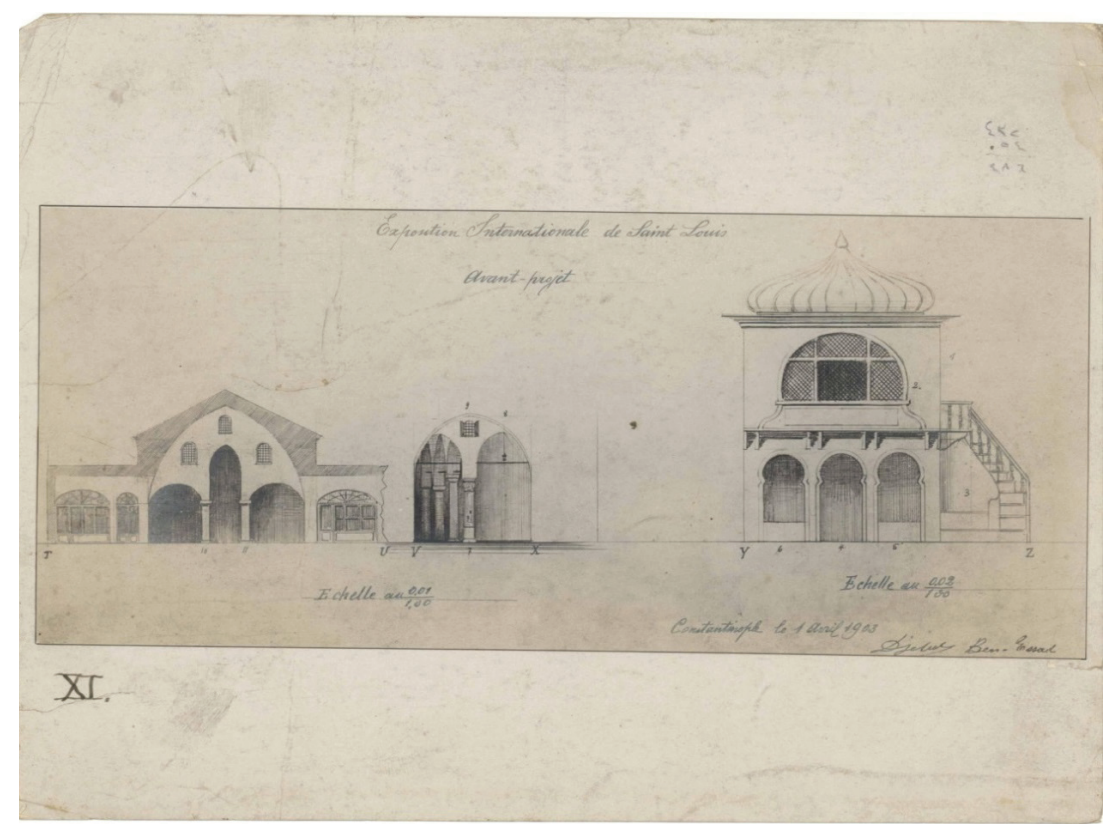

G. 18. Kapalıçarşı'nın içini gösteren kesitler (İBB Atatürk Kitaplığı)

XII, XIV ve XV. çizimlerse Türk mahallelerini tanıtmak adına çizilmiş cephe ve sokak görüntüleridir ve büyük olasılıkla sadece sergilenmiştir. (G. 19-G. 21) Bunlar muhtemelen İstanbul' da bazı evlerdir ve en ufak ayrıntılarına kadar resmedilmiştir. Kimisi daha basit kimisi daha gösterişli olan evler, taş, tuğla ve ahşap malzemeli 
olarak, konsol, çıkma, pencerelerin önündeki ahşap paravanlar ve sundurmalarıyla geleneksel Türk konut mimarisini yansitmaktadır.

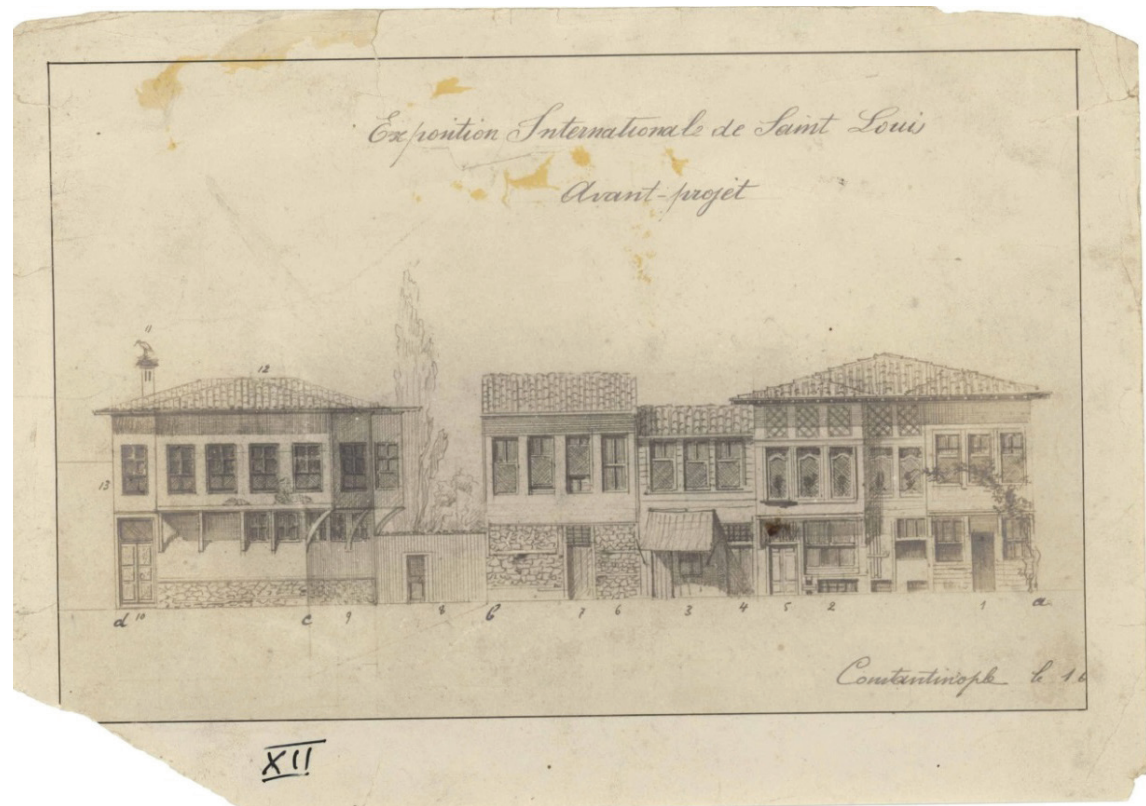

G. 19. Türk mahallesi ve evi görünümü (İBB Atatürk Kitaplığı)

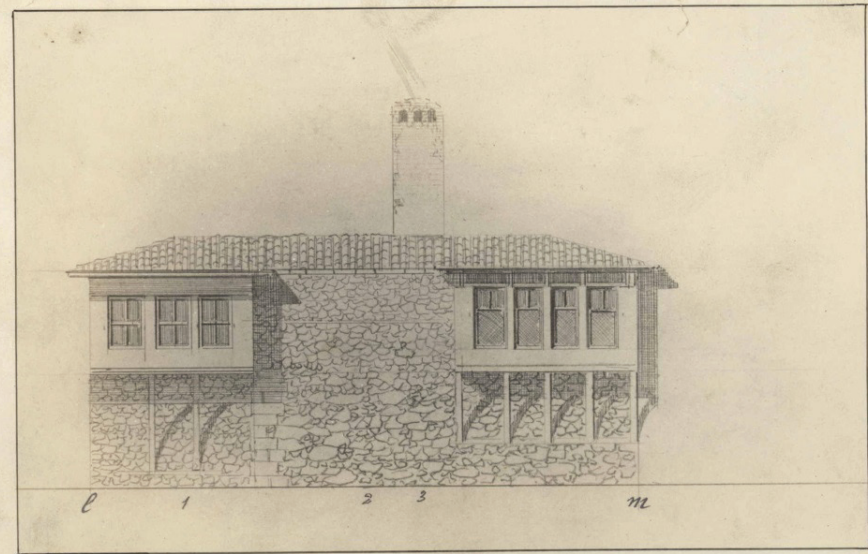

XIV.

G. 20. Türk evi görünümü (İBB Atatürk Kitaplığı) 


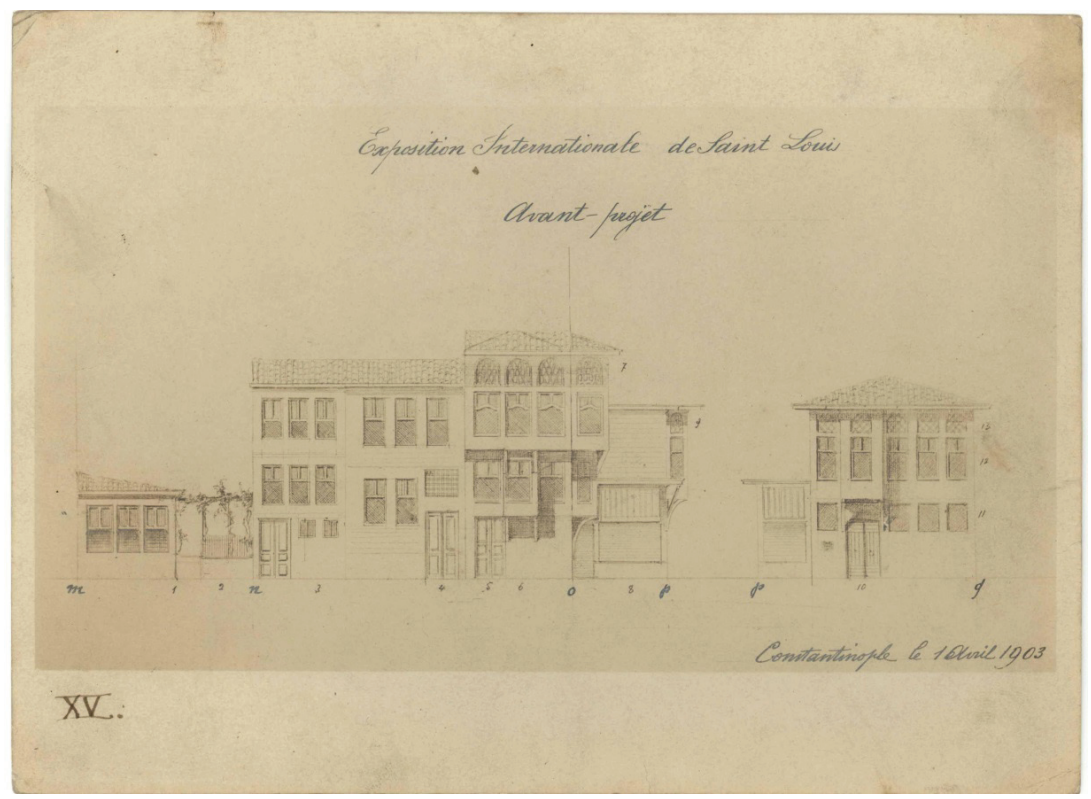

G. 21. Türk mahallesi ve evi görünümü (İBB Atatürk Kitaplı̆̆g)

\section{Sonuç}

Osmanlı İmparatorluğu açısından sergiler, kendisini ifade edebilmek için çoğu zaman bir araç olmuştur. Fuarlara katılmakla bir taraftan Müslüman dünyanın halifesi ve temsilcisi, bir taraftan modern dünya ülkeleri içinde saygın bir devlet olduğunu göstermek istemiştir. Avrupa'da ortaya çıktığı dönemde fuarlarda mimari temsiller bulunmazken sonradan kültür odaklı sergilere ilgi artmış ve bunun sonucu mimari sergiler hazırlanmıştır. Osmanlı İmparatorluğu fuarların büyük bir kısmına çeşitli mimarlık eserleriyle ve hepsinde yabancı bir mimarın Türk mimarisini esas alan tasarımlarıyla katılmıştır. 1904 St. Louis Fuarı'ndaysa Osmanlı'ya küçük bir alan ayrılmış ve çeşitli ürünler bu fuarda sergilenmiştir. Fuara ilişkin çok sayıda görsel kaynak bulunmakla birlikte bunlar içinde Osmanlı pavyonunu tam manasıyla gösteren bir kaynağa ulaşılamamaktadır. Nitekim bugüne kadar bu sergiye Osmanlı'nın Kapalıçarşı reprodüksiyonuyla katıldığına sınırlı sayıda kaynaktaki bilgilerle değinilmiş, sergi için yapılan projeler hiç görülmemiştir.

Serginin yapılacağı 1904 senesinde imparatorluk çöküş dönemini yaşamakta ve maddi imkânsızlıklarla boğuşmaktadır. Celal Esad Arseven, bu yıllarda sultanın yakınında olmasına rağmen siyasi ya da ekonomik sebeplerle sergiye gönderilmemiştir. Kendi ağzından yayımlanan hatıra kitabında sultanın bu sergiye gitmesine izin vermediğini dile getirmiş ancak sebebini belirtmemiştir. 1903 senesinin Nisan ayında yaklaşık bir ay gibi kısa bir sürede hazırladığı Kapalıçarşı ağırlıklı olmak üzere çeşitli sokak ve ev görünümleriyle Türk mimarisini yansitan üslup ve özelliklerdeki mimari elemanlarını sergilemeye çalışmıştır. Yine fuar bültenine verdiği röportajda kendi 
deyimiyle amacı "Türk mimarisini doğru tanıtmak ve sultanın şöhretini arttırmaktır". Amerikalı Pangalo'nun aracılık ettiği bu sunum kuşkusuz Celal Esad Arseven için de yeni ufuklar açmış, Türk mimari tarihine ilişkin bilgi ve araştırmalarının temelini oluşturmuştur. Bu projeyi hazırladıktan sonra yaptığı araştırmaları kitap olarak yayımlamıştır. Fransızca olarak hazırladığ 1 bu kitap yazıldığ başarmıştır. Hiç kuşku yok ki Celal Esad Arseven Türk sanat tarihi için önemli bir figürdür, yapıtları ve eserlerinin niteliği üzerinde durulmayı hak etmektedir.

\footnotetext{
Hakem Değerlendirmesi: Dış bağımsız.

Çıkar Çatışması: Yazar çıkar çatışması bildirmemiştir.

Finansal Destek: Yazar bu çalışma için finnansal destek almadığını beyan etmiştir.

Peer-review: Externally peer-reviewed.

Conflict of Interest: The author has no conflict of interest to declare.

Grant Support: The author declared that this study has received no financial support.
}

\section{Kaynakça/References}

Adıgüzel, Hatice. “Bir Tasarımın İzinde: Yeni Bulgular Işı̆ğında Raimondo D’Aronco'nun İlk İstanbul Projesi Dersaadet Ziraat ve Sanayi Sergi-i Umumisi.” METU JFA 36, no. 1 (2019): 157-182. Erişim 19 Kasım 2019, http://jfa.arch.metu.edu.tr/archive/0258-5316/articles/metujfa2019104.pdf

Akozan, Feridun. Celal Esad Arseven 'in Biyografisi. Demirbaş No: Bel_Mtf_003701. Erişim 7 Mart 2019, http://ataturkkitapligi.ibb.gov.tr/kutuphane3/Evraklar/Bel_Mtf_003701.pdf

Arseven, Celal Esad. Eski Galata ve Binaları. Ed. Dilek Yelkenci. İstanbul: Çelik Gülersoy Vakfi Yayınlar1, 1989.

Arseven, Celal Esad. Güzel Sanatlar Terimleri Alanında Öncü Bir Çalışma, Sanâyi'-i Nefîse Istılâhâtı Mecmûası. Ed. Nurcan Yazıcı. İstanbul: Mimar Sinan Güzel Sanatlar Üniversitesi Yay1nlar1, 2000.

Arseven, Celal Esad. Osmanlı Dönemi Mimarlık Sözlüğü, Istılâhât-ı Mi'mariyye. Çev. Şeyda Alpay. İstanbul: Kaknüs Yayınları, 2017.

Arseven, Celal Esad. Sanat ve Siyaset Hatıralarım. Ed. Ekrem Işın. İstanbul: İletişim Yayınları, 1993.

Celal Esad Arseven Anısına Sanat Tarihi Semineri Bildirileri. Ed. Banu Mahir, İstanbul: Mimar Sinan Üniversitesi Matbaas1, 2000.

Çelik, Zeynep. Displaying the Orient-Architecture of Islam at Nineteenth-Century World's Fair. Berkeley: University of California Press, 1992.

Cephanecigil, V. Gül. "Geç Osmanlı ve Erken Cumhuriyet Dönemlerinde Mimarlık Tarihi İlgisi ve Türk Eksenli Milliyetçilik (1873-1930).” Doktora tezi. İstanbul Teknik Üniversitesi, 2009.

Deringil, Selim. İktidarın Sembolleri ve İdeoloji-II. Abdülhamid Dönemi. Çev. Gül Çağalı Güven, İstanbul : Doğan Kitap Yayınları, 2014.

Eyice, Semavi. "Büyük Çarş1.” Türkiye Diyanet Vakfi İslam Ansiklopedisi 6 (1992):509-513.

Eyice, Semavi. “Celal Esad Arseven, 1875-1971.” Belleten 36 (1972): 173-202.

Francis, David Rowland. The Universal Exposition of 1904, St. Louis 1913. Erişim 10 Şubat 2019 https://babel.hathitrust.org/cgi/pt?id=mdp.39015010951427;view=1up;seq=9. 
İnalcık, Halil. “Osmanlılar'da Batı'dan Kültür Aktarması Üzerine.” Osmanlı Imparatorluğu-Toplum ve Ekonomi. İstanbul: Eren Yayınları, 1993, 195-200.

İrade Hariciye (İ.HR.), 386-7. (24 Recep 1321), Cumhurbaşkanlığı Devlet Arşivleri Osmanlı Arşivi.

Gülersoy, Çelik. Story of the Grand Bazaar. İstanbul: İstanbul Kitaplığı, 1990.

Kuban, Doğan. “Celal Esad Arseven ve Türk Sanatı Kavramı.” Mimarlık 72 (1969): 18-20.

Louisiana and the Fair: An Exposition of the World, Its People, and Their Achievements 5. Ed. James William Buel (St. Louis: World's Progress Publishing Company, 1904). Erişim 1 Şubat 2019, https://babel.hathitrust.org/cgi/pt?id=uc2.ark:/13960/t1cj89b26;view=1up;seq=10.

Louis, Bréhier. “Djelal-Essad Bey, Constantinople. De Byzance à Stamboul.” Journal Des Savants 9 (1911): 44-54.

Mattie, Erik. World's Fairs. New York: Princeton Architectural Press, 1998.

Önsoy, Rıfat. “Osmanlı İmparatorluğu'nun Katıldığ 1 İlk Uluslararası Sergiler ve Sergi-i Umumi-i Osmani 1863 İstanbul Sergisi.” Belleten 185 (1983): 195-235.

Özer, Bülent. “Celal Esad Arseven.” Mimarlık 72 (1969): 21-24.

Şirin, İbrahim. "Dünya Fuarları ve Osmanlı Modernleşmesi.” History Studies 9/2 (2017): 189-204.

Tunaya, Tarık Zafer. Türkiye'nin Siyasi Hayatında Batılılaşma Hareketleri. İstanbul: Yedigün Matbaas1, 1960.

Universal Exposition, St. Louis, U.S.A., 1904: Commemorating the Acquisition of Louisiana Territory: It's Story and Purpose, St. Louis: The Exposition 1904. Erişim 10 Şubat 2019 https://babel. hathitrust.org/cgi/pt?id=uc1.31175014412988;view=1up;seq=3;size=125.

World Fair's Bulletin, 1903.

Yazıcı, Nurcan. "19. Yüzyıl Uluslararası Sergilerinde Bir Osmanlı Simgesi-III. Ahmet Çeşmesi.” Toplumsal Tarih 134 (2005): 84-91.

Yazıc1, Nurcan. “Uluslararası Sergilerde Osmanlı Mimarisi'nin Sunumu.” Arkitekt 500 (2004): $18-31$.

Yıldız Perakende Evrakı Mabeyn Başkitabeti (Y. PRK. BŞK.), 71-6. (19 Recep 1321), Cumhurbaşkanlığı Devlet Arşivleri Osmanlı Arşivi.

İBB Atatürk Kitaplığı Sayısal Arşiv ve e- Kaynaklar, Demirbaş No: Bel_Mtf_003724

Exposition Internationale de Sant - Louis avant projét. Planche VIII. [Celal Esat Arseven'in Uluslararası Sant - Louis fuarına Türk Mimarisi örneklerinin yer aldığı Eminönü - Kalpakçılar ve Nuruosmaniye caddeleri ile Kavaflar ve Aynacılar çarşıları ve civarı haritasının fotoğrafıdır] (http://ataturkkitapligi.ibb.gov.tr/kutuphane3/Evraklar/Bel_Mtf_003724.pdf. /Erişim 05.03.2019)

İBB Atatürk Kitaplığı Sayısal Arşiv ve e- Kaynaklar, Demirbaş No: Bel_Mtf_003717

Exposition Internationale de Sant - Louis avant projét. Planche II. [Celal Esat Arseven'in Uluslararası Sant - Louis fuarına Türk Mimarisi örneklerinden çizdiği projedir] (http://ataturkkitapligi. ibb.gov.tr/kutuphane3/Evraklar/Bel_Mtf_003717.pdf/Erişim 05.03.2019)

İBB Atatürk Kitaplığı Sayısal Arşiv ve e- Kaynaklar, Demirbaş No: Bel_Mtf_003715

Exposition Internationale de Sant - Louis avant projét. Planche III. [Celal Esat Arseven'in Uluslararası Sant - Louis fuarına Türk Mimarisi örneklerinden çizdiği projedir] (http:// ataturkkitapligi.ibb.gov.tr/kutuphane3/Evraklar/Bel_Mtf_003715.pdf/Erişim 05.03.2019)

İBB Atatürk Kitaplığı Sayısal Arşiv ve e- Kaynaklar, Demirbaş No: Bel_Mtf_003712 
Exposition Internationale de Sant - Louis avant projét. Planche IV. [Celal Esat Arseven'in Uluslararası Sant - Louis fuarına Türk Mimarisi örneklerinden çizdiği projedir] (http://ataturkkitapligi. ibb.gov.tr/kutuphane3/Evraklar/Bel_Mtf_003712.pdf/Erişim 05.03.2019)

İBB Atatürk Kitaplığı Sayısal Arşiv ve e- Kaynaklar, Demirbaş No: Bel_Mtf_003714

Exposition Internationale de Sant - Louis avant projét. Planche V. [Celal Esat Arseven'in Uluslararası Sant - Louis fuarına Türk Mimarisi örneklerinden çizdiği projedir] (http://ataturkkitapligi. ibb.gov.tr/kutuphane3/Evraklar/Bel_Mtf_003714.pdf/Erişim 05.03.2019)

İBB Atatürk Kitaplığı Sayısal Arşiv ve e- Kaynaklar, Demirbaş No: Bel_Mtf_003713

Exposition Internationale de Sant - Louis avant projét. Planche VI. [Celal Esat Arseven'in Uluslararası Sant - Louis fuarına Türk Mimarisi örneklerinden çizdiği projedir] (http://ataturkkitapligi. ibb.gov.tr/kutuphane3/Evraklar/Bel_Mtf_003713.pdf/Erişim 05.03.2019)

İBB Atatürk Kitaplığı Sayısal Arşiv ve e- Kaynaklar, Demirbaş No: Bel_Mtf_003711

Exposition Internationale de Sant - Louis avant projét. Planche VII. [Celal Esat Arseven'in Uluslararası Sant - Louis fuarına Türk Mimarisi örneklerinden çizdiği projedir] (http://ataturkkitapligi. ibb.gov.tr/kutuphane3/Evraklar/Bel_Mtf_003711.pdf/Erişim 05.03.2019)

İBB Atatürk Kitaplığı Sayısal Arşiv ve e- Kaynaklar, Demirbaş No: Bel_Mtf_003723

Exposition Internationale de Sant - Louis avant projét. Planche VIII. [Celal Esat Arseven'in Uluslararası Sant - Louis fuarına Türk Mimarisi örneklerinden çizdiği projedir] (http://ataturkkitapligi. ibb.gov.tr/kutuphane3/Evraklar/Bel_Mtf_003723.pdf/Erişim 05.03.2019)

İBB Atatürk Kitaplığı Sayısal Arşiv ve e- Kaynaklar, Demirbaş No: Bel_Mtf_003721

Exposition Internationale de Sant - Louis avant projét. Planche IX. [Celal Esat Arseven'in Uluslararası Sant - Louis fuarına Türk Mimarisi örneklerinden çizdiği projedir] (http://ataturkkitapligi. ibb.gov.tr/kutuphane3/Evraklar/Bel_Mtf_003721.pdf/Erişim 05.03.2019)

İBB Atatürk Kitaplığı Sayısal Arşiv ve e- Kaynaklar, Demirbaş No: Bel_Mtf_003722

Exposition Internationale de Sant - Louis avant projét. Planche X. [Celal Esat Arseven'in Uluslararası Sant - Louis fuarına Türk Mimarisi örneklerinden çizdiği projedir] (http://ataturkkitapligi. ibb.gov.tr/kutuphane3/Evraklar/Bel_Mtf_003722.pdf/Erişim 05.03.2019)

İBB Atatürk Kitaplığı Sayısal Arşiv ve e- Kaynaklar, Demirbaş No: Bel_Mtf_003719

Exposition Internationale de Sant - Louis avant projét. Planche XI. [Celal Esat Arseven'in Uluslararası Sant - Louis fuarına Türk Mimarisi örneklerinden çizdiği projedir] (http://ataturkkitapligi. ibb.gov.tr/kutuphane3/Evraklar/Bel_Mtf_003719.pdf/Erişim 05.03.2019)

İBB Atatürk Kitaplığı Sayısal Arşiv ve e- Kaynaklar, Demirbaş No: Bel_Mtf_003718

Exposition Internationale de Sant - Louis avant projét. Planche XII. [Celal Esat Arseven'in Uluslararası Sant - Louis fuarına Türk Mimarisi örneklerinden çizdiği projedir] (http://ataturkkitapligi. ibb.gov.tr/kutuphane3/Evraklar/Bel_Mtf_003718.pdf/Erişim 05.03.2019)

İBB Atatürk Kitaplığı Sayısal Arşiv ve e- Kaynaklar, Demirbaş No: Bel_Mtf_003720

Exposition Internationale de Sant - Louis avant projét. Planche XI. [Celal Esat Arseven'in Uluslararası Sant - Louis fuarına Türk Mimarisi örneklerinden çizdiği projedir] (http://ataturkkitapligi. ibb.gov.tr/kutuphane3/Evraklar/Bel_Mtf_003720.pdf/Erişim 05.03.2019)

İBB Atatürk Kitaplığı Sayısal Arşiv ve e- Kaynaklar, Demirbaş No: Bel_Mtf_003716

Exposition Internationale de Sant - Louis avant projét. Planche XV. [Celal Esat Arseven'in Uluslararası Sant - Louis fuarına Türk Mimarisi örneklerinden çizdiği projedir] (http://ataturkkitapligi. ibb.gov.tr/kutuphane3/Evraklar/Bel_Mtf_003716.pdf/Erişim 05.03.2019) 